\title{
INFLUENCIA, POR SELECGIÓN, DE AMÉRICA EN SU ARTE COLONIAL
}

Manuel González Galván

Desde la segunda mitad del siglo XIX, en que se inicia la revaloración del arte colonial latinoamericano, y por sobre todo en lo que va de nuestro siglo, se ha dado entre los historiadores, críticos y gustadores de este arte, una intensa preocupación por dilucidar las influencias que ha recibido por parte de lo indigena, lo mestizo, lo popular y lo criollo, así en este orden, sin olvidar que en algunas áreas y casos, que son los menos, la presencia negra tiene también su importancia. El interés esencial de tal preocupación es descubrir la americaneidad producida en el arte del continente por el hombre de origen no europeo. Es de advertir que, pese a discusiones racistas ya superadas, en el caso de la expresión artística, las opiniones se apoyan en consideraciones no tanto de raza cuanto en relación a circunstancias socioculturales, a veces políticoeconómicas, pero siempre acordes en que el más fuerte factor de convergencia o elemento de imbricación aglutinante lo constituyó durante los siglos coloniales, la religión.

Desde un principio no se puso en duda la capacidad creativa indígena sino antes bien se la descubrió con entusiasmo y son los propios frailes evangelizadores los primeros en dejar testimonio de ello, basta recordar algunas de sus frases.

Fray Jerónimo Mendieta nos dice en su Historia Eclesiástica Indiana:

...por regla general .., cuasi todas las buenas y curiosas obras que en todo género de oficios y artes se hacen en esta tierra de Indias (a lo menos en la Nueva España), los indios son los que ejercitan y labran, porque los españoles maestros de tales oficios, por maravilla hacen más que dar la obra a los indios y decirles cómo quieren que la hagan. Y ellos la hacen tan perfecta, que no se puede mejorar.

Fray Toribio de Benavente apunta en su Memoriales o libro de las cosas de la Nueva España:

Estos naturales (tienen) grande ingenio e habilidad, la cual habilidad parece por todas las ciencias, artes e oficios que les han enseñado, por que con todos han salido, y en muy breve tiempo que no otras naciones, en tanta manera, que en venido(s) los oficios que en Castilla están muchos años en los deprender acá en sólo mirarlos y verlos hacer, han muchos quedado maestros, y de esto espantados los españoles, dicen que los indios en sólo mirar los oficios los contrahacen.

A su vez, Fray Bartolomé de Las Casas, con amorosa actitud hacia el indigena anota en su Apologética Historia Sumaria... 
... todo esto questá dicho les proviene (a los indios), y es manifiesta señal de tener... excelente y maravillosa virtud y potencia de imaginación.

Ahora bien, en qué forma y hasta qué grado "contrahicieron", como diría Benavente, los indígenas el arte impuesto, es lo que a la crítica más cercana a nosotros ha preocupado y de lo que aqui queremos tratar, para esto escucharemos una serie de opiniones en las que sin poner en duda la facultad creativa aborigen sí se cuestionan los límites de su influencia y su presencia, en búsqueda del esclarecimiento de la originalidad y autonomía del arte colonial. Espigaremos entre citas de los más distinguidos investigadores que han tocado el problema, advirtiendo que la índole de este trabajo impide una revisión más amplia, por lo que tan sólo algunos párrafos sugerentes se incluyen a sabiendas de que existe ya un gran número de críticos y títulos que enriquecen la bibliografía del tema, al grado de ser esto digno de una recopilación específica. ${ }^{1}$

Empecemos con José Moreno Villa, el inventor del discutido término "Tequitqui", quien nos dice:

durante el siglo XVI es cuando se producen aquí las esculturas más interesantes; precisamente porque al contacto de las diferentes razas surge un conato de estilo que, por analogía con el mudéjar, llamo "Tequitquii" 2

.vasallos y tributarios fueron aquí los indios, ¿porqué no buscar la palabra equivalente en azteca y bautizar con ella .... a las obras que presentan rasgos de especialísima amalgama de estilos? ... yo propongo la antigua voz mexicana "Tequitqui", o sea, tributario ${ }^{3}$

el indigena introducía en sus monumentos o en las imágenes de sus divinidades, un elemento precioso, extraño al monumento mismo, cuya misión era darle vida, de la misma manera que el corazón humano es el símbolo de la vida del hombre. Solía ser de obsidiana ${ }^{4}$

aunque durante los siglos siguientes encontramos obras con ese mismo carácter "tributario" o Tequitqui, ya no van teniendo rasgos tan arcaicos, tan románicos y góticos.

Moreno Villa se da cuenta de que este arte que surge a partir del siglo XVI es pues "tributario" pero que resulta no obstante un "conato de estilo" que

'Fernández Garciá, Martha Rạuel. Histưra del concepto de "1nte tequtqu"." Tesis para optar al grado de Licenciado en Historia, UNAM, México, 1976. En esta tesis se desarrolla una muy completa investigación en relación al arte "tequitqui". De ella hemos estractado algunas de las citas que anotamos

2 Moreno Villa, José La escultura colonial mexicana El Colegio de México México, 1942, p. 110

Ibidem, p. 16

4 Ibidem, p. 19

${ }^{3}$ Moreno Villa, José Lo mexicano en las artes pláslicas El Colegio de México México, 1948, p 174 
lo hace diferente y por analogía inventa el término que en adelante será tan discutido, también se da cuenta de algunas intromisiones directas de origen prehispánico como los discos de jade u obsidiana, lo que ya advirtió también Rafael García Granados como "Reminiscencias idolátricas en monumentos coloniales", comprobables en cruces atriales como las de San Felipe de los Alzates y San José Tajimaroa, (Hoy Ciudad Hidalgo), en Michoacán (figuras 1 y 2)

Moreno Villa percibe también que habrá una persistencia de ese mismo carácter en los dos siglos siguientes aunque sin el arcaísmo Tequitqui.

El ilustre Manuel Toussaint, a quien tanto debe la investigación del arte colonial en México, piensa que:

si los indios no podian influir en forma decisiva sobre el arte europeo, a causa de la gran diferencia que existía entre las dos manifestaciones artísticas y aún entre los imperativos sociales que las causaban, es imposible dejar de ver, sobre todo en creaciones escultóricas, la mano india que recuerda su técnica y que a veces tiene presentes sus modelos ${ }^{\text {? }}$

Conservamos cierto número de piedras en las que, sobre la índole del objeto, no sólo la mano de obra, sino el propio espíritu indigena ha podido sobrevivir. ${ }^{8}$

la importancia del patio fue tan grande en los tiempos primitivos como el mismo templo, y no podemos menos que recordar las grandes explanadas que constituían la parte primordial del templo indígena: es acaso la última remembranza, el solo punto en que podemos hablar de una sutil supervivencia indigena en la arquitectura religiosa del virreinato, no decorativa sino de elementos básicos ${ }^{9}$ (figura 3 )

la cultura europea no se implantó de golpe; fué sustituyendo paulatinamente a las costumbres indigenas y en más de un caso el elemento aborigen predominó sobre el extranjero... ciertos elementos del arte indígena persistieron durante toda la colonia y llegaron al mismo México independiente ${ }^{10}$

Vemos así que Toussaint también es perfectamente consciente de las limitaciones expresivas del nativo ante el arte europeo, pero que no pueden ser negadas algunas presencias de sus modelos antiguos y tampoco sólo su mano de obra sino "el propio espíritu indígena", a más de algunas remembranzas esencialmente espaciales y no únicamente decorativas, como los grandes atrios con sus posas y capillas abiertas. (liguras + y 5 ) Aparte de que tam-

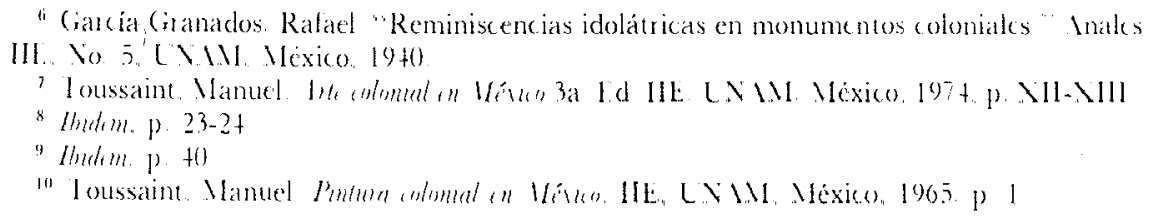


bién "ciertos elementos", algo aborigen persiste durante todo el coloniaje y hasta el México independiente, ese algo que después nos habrá de ocupar más detalladamente

Justino Fernández, quien tuvo como principal ocupación de su basta obra crítica sintetizar las grandes eta pas del arte mexicano, resumidas en sus tres significativos libros que son (nallue, para lo prehispánico, El Relablo de los Reyes, para lo colonial y lil llombre, para lo moder no y contemporáneo, no podía dejar de tomar en consideración el tema que nos ocupa y al hablar de los estudios acerca del arte mexicano colonial dice:

aparecen... dos preocupaciones que podemos reconocer como tradicionales: primero, lo que hay de indigena en esas obras, o "la mano indigena" en ellas; segundo, su carácter inconfundiblemente mexicano, al grado que se diferencian no sólo de las europeas, sino aun de las de otros países americanos, de donde brota el orgullo ante la conciencia del valor de lo propio. ${ }^{11}$

En otro párrafo nos dice:

existen unas formas, unas cualidades y un espíritu indígenas en el arte de la Nueva España, ya sean en obras del siglo XVI, o bien en las barrocas populares del siglo XVIII Y la presencia de ese espíritu, formas y cualidades, es lo que hace singular para algunos el arte novohispano ${ }^{12}$ (figura 6)

Como se ve, Justino Fernández también considera que hay algo en el arte novohispano que lo hace diferente de lo europeo y que estas cualidades se deben a un "espíritu indigena", no sólo manifiesto en el siglo XVI sino persistente hasta obras barrocas del siglo XVIII

$Y$ así otros investigadores coinciden en sus consideraciones por explicar lo distinto del arte colonial, Jorge Alberto Manrique anota lo siguiente:

. las alteraciones que las formas occidentales de España sufrieron al ser trasplantadas a México se deben, más que a una nunca definida influencia del arte prehispánico, a una mala lectura de los modelos propuestos, debidà a la diferente situación cultural de quienes debían realizarlos en este lado del Atlántico. ${ }^{13}$

Estamos de acuerdo con esta diferente lectura de las formas europeas pero

\footnotetext{
"Fernández, Justino Estética del Arte Mexicano: Coallicue El Retablo delos Reyes El Hombre 2 a Ed. IIE, UNAM, México, 1972, p. 275

1: Iludrm. p. 294

13 Manrique, Jorge Alberto "El trasplante de las formas artisticas españolas a México." Aulas dol Tireer Congreso Internatonal de Hupanustas. El Colegio de México, 1969, p. 575
} 
que no necesariamente por eso es mala, punto que después trataremos de aclarar

Elisa Vargas Lugo también observa que este carácter de diferenciación local no se manifiesta tan sólo en el siglo XVI sino que perdura en toda la colonia y nos dice que:

Dada la riqueza formal hibrida de las portadas Tequitqui y por ende su esencial libertad artística, nos parece que además de la importancia que tienen con ser las primeras obras de arte mexicano, también tienen el mérito de haber preparado el camino a la exuberancia barroca que tan rápidamente se desató a partir del siglo XVII. Las portadas Tequitqui son en cierto modo precursoras de las portadas populares barrocas de argamasa, que se cubren totalmente de relieves, en cuanto al gusto por la ornamentación y la libertad de expresión, si bien las portadas del XVII son ya plenamente barrocas, sin mezcla de elementos tequitqui, pero no cabe duda que el mismo gusto popular, indígena, amante de las formas profusas y aglomeradas está presente en ambos estilos ${ }^{14}$

O sea que aún dentro del cambio de estilos hay una constante de influencia nativa que transforma el repertorio formal venido de allende el mar.

Constantino Reyes Valerio ha dedicado gran parte de su labor de investigación a esclarecer el grado de influencia y presencia de formas indigenas en el arte colonial, especialmente del siglo XVI, lo que sintetiza en su libro Arte Indocristiano, del que extraemos lo siguiente:

La búsqueda de las pruebas indirectas de la intervención indígena en el arte monástico mexicano, me llevó al encuentro de ciertos hechos ya sospechados pero poco investigados, o sea al hallazgo cada vez más frecuente de las formas de la iconografía prehispánica. Esto implicó la necesidad de conocer, hasta donde me fuese posible, la infinita variedad de formas expresivas del pensamiento indigena conservado en la escultura y la cerámica pero principalmente en los códices, a efecto de poder separar lo que es europeo y lo que es o podría ser indígena La tarea no fue sencilla, porque existen motivos que tanto pueden ser nativos como extranjeros, es decir, que hay una coincidencia formal. Pero este mismo hecho pudo prestarse para que el indigena pudiese expresar un concepto sin temor a que fuese castigado por los frailes que, en ese tiempo, trataron de evitar toda manifestación de las creencias ancestrales consideradas como paganas y en abierta oposición a la fe cristiana que iban implantando poco a poco. ${ }^{15}$

Interesa subrayar de lo anterior el " ....poder separar lo que es europeo y lo

14 Vargas Lugo, Elisá Las partadas religiosas de Méxzo IIE, UNAM, México, 1969, p. 270-271.

15 Reyes Valerio, Constantino Arte Indocristzano SEP, INAH, México, 1978, p. 10 
que es o podría ser indígena", que "existen motivos que tanto pueden ser nativos como extranjeros, es decir, que hay una coincidencia formal", y a esta coincidencia formal le prestaremos mayor atención más adelante.

Como una opinión más de esta subyacente y permanente presencia de lo indígena a través de todo el arte novohispano y de que es claro que esto indigena no tiene implicación racial más que como concepto de lo nativo, nos dice la voz distinguida y autorizada de Enrique Marco Dorta:

En un reciente libro de síntesis agrupé algunos de los ejemplos que consideré más representativos, bajo el epígrafe: "arte barroco de influencia indígena" ...en casi todo el país, se encuentran muestras de un arte barroco que, en lo decorativo, es bien diferente del característico de las escuelas locales de las ciudades o comarcas en que ese otro aspecto florece. Sin desaparecer la vieja estirpe hispana, se diria que asoma la raza mexicana dejando la huella de su especial sensibilidad -india, mestiza o criolla- en la manera de interpretar los temas ornamentales, en la factura o bisel o de trépano del relieve y en el afán de cubrir enteramente los paramentos con la ornamentación, como si los artistas estuviesen poseídos del "horror al vacio". Aunque ese arte se produce paralelamente al arte sabio de las ciudades y en contraste con él, no me parece acertado considerarlo como "popular", término más propio de creaciones artesanas que para auténticas obras de arte. Como tampoco me parece exacto el calificativo de "mestizo" -que implica mezcla de razas -, preferí agrupar esos monumentos barrocos bajo el epígrafe antes citado, dando al vocablo "indígena" el sentido amplio de hombre del lugar, cualquiera que sea la sangre que corra por sus venas. ${ }^{16}$

Como se ve, en lo que hasta aquí hemos llegado, las referencias se ocupan básicamente del arte colonial en México, esto porque en lo personal nos es el más cercano y mejor conocido, pero de ninguna manera el interés por su singularidad excluye la que existe en otras naciones y regiones continentales, de esto se han ocupado innumerables y distinguidos historiadores y críticos, que aquí nos sería imposible recordar, pero baste la mención de Harold $\mathrm{E}$. Whethey, quien como Moreno Villa inventa lo del Tequitqui, Whethey propone para Suramérica, especialmente en el área andina, lo del "arte mestizo", tan discutido o más que lo Tequitqui.

José de Mesa y Teresa Gisbert han desarrollado una larga y fructífera tarea en esta área así como tantos otros entre los que no se puede pasar por alto

${ }^{16}$ Marco Dorta, Enrique.. "Consideraciones en torno al llamado 'estilo tequitqui'." Coloquio Internacional de Zacatecas: Dicotomía entre arte culto y arte popular. IIE, UNAM, 1975

17 Whethey, Harold E. Colonial Archtecture and Sculpture in Perú, Cambridge, Harvard Univer sity, 1949, y Arquitectura Virreinal en Bolivia, La Paz, Universidad Mayor de San Andrés, 1960 . En estas obras Whethey comienza a usar la denominación de "arquitectura mestiza" y "estilo mestizo". 


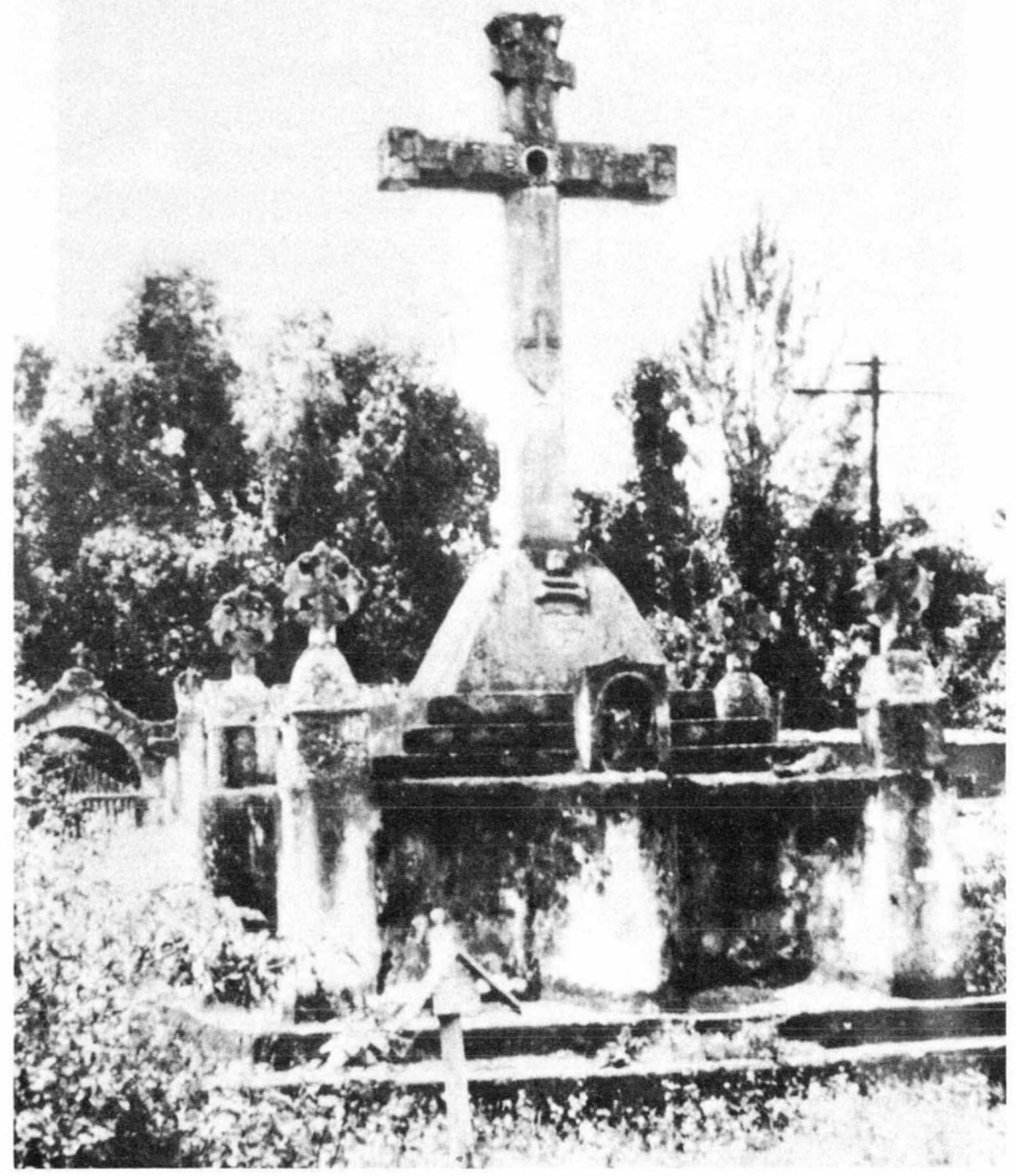

Figura 1. San Felipe de los Alzates, Mich., Cruz atrial del siglo XVI, con disco de obsidiana en el cruce de los brazos. 


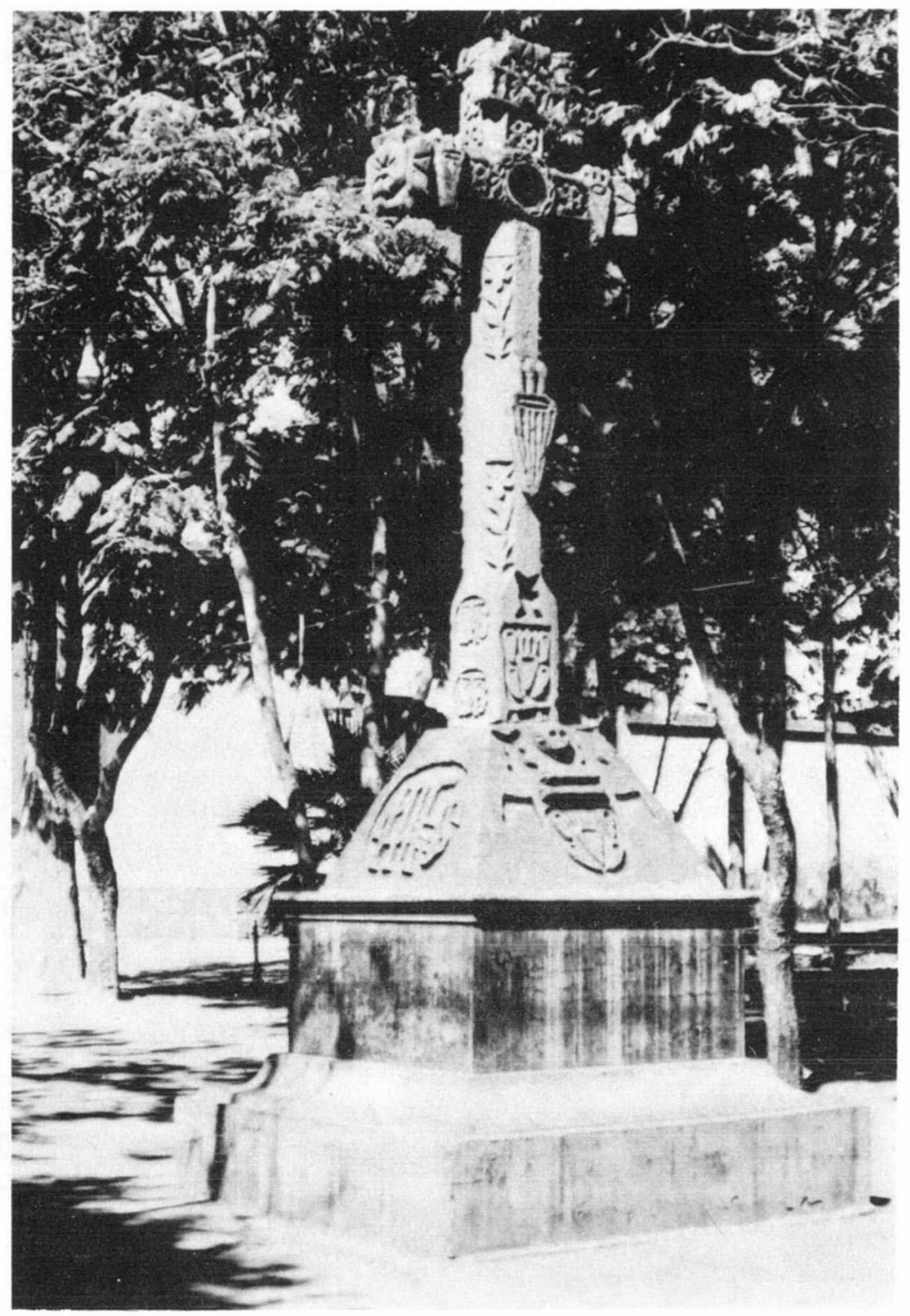

Figura 2. San José Tajimaroa, (Hoy Ciudad Hidalgo), Mich., Cruz del siglo XVI, en el atrio conventual franciscano. Lleva disco de obsidiana en el cruce de los brazos. 


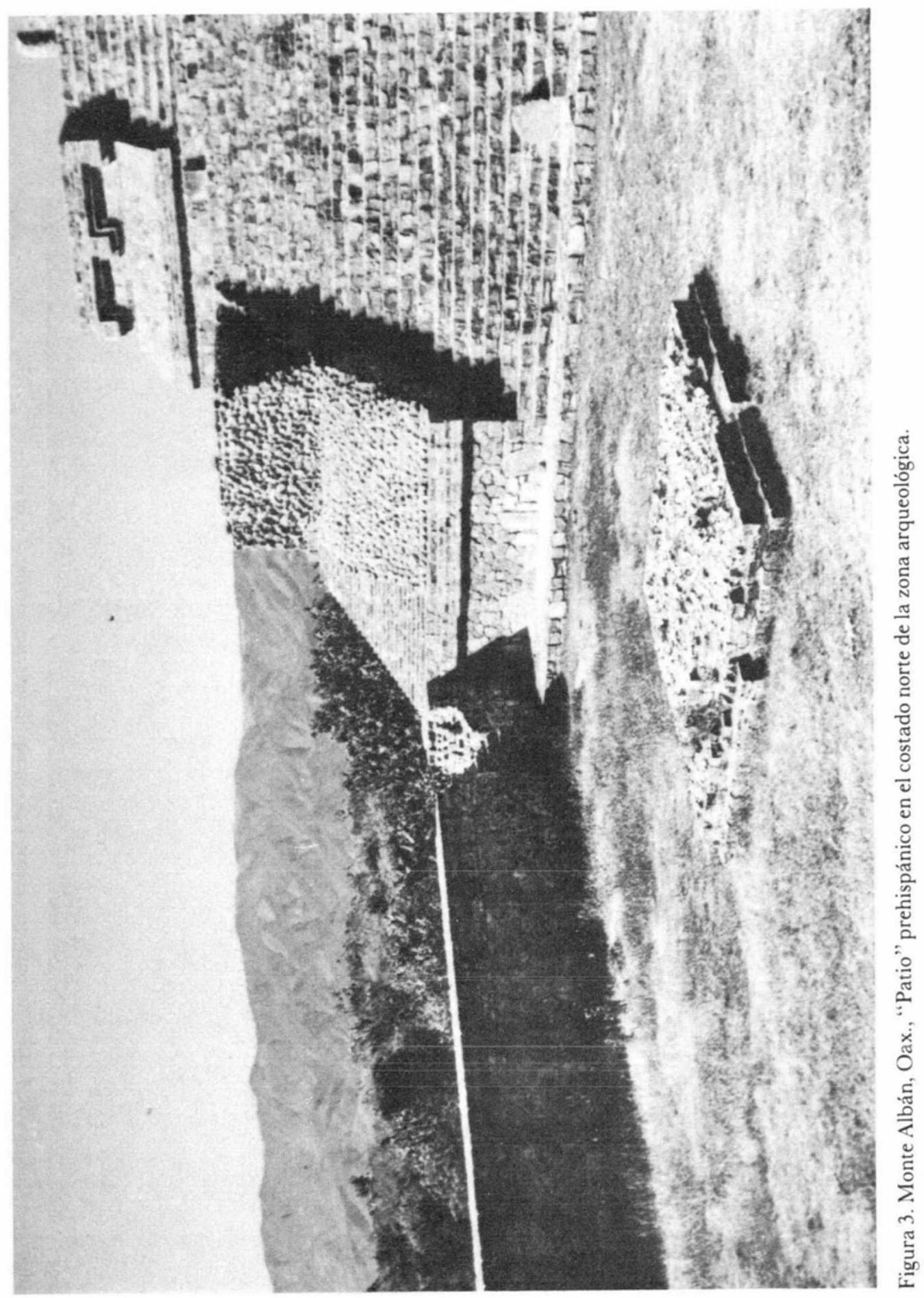




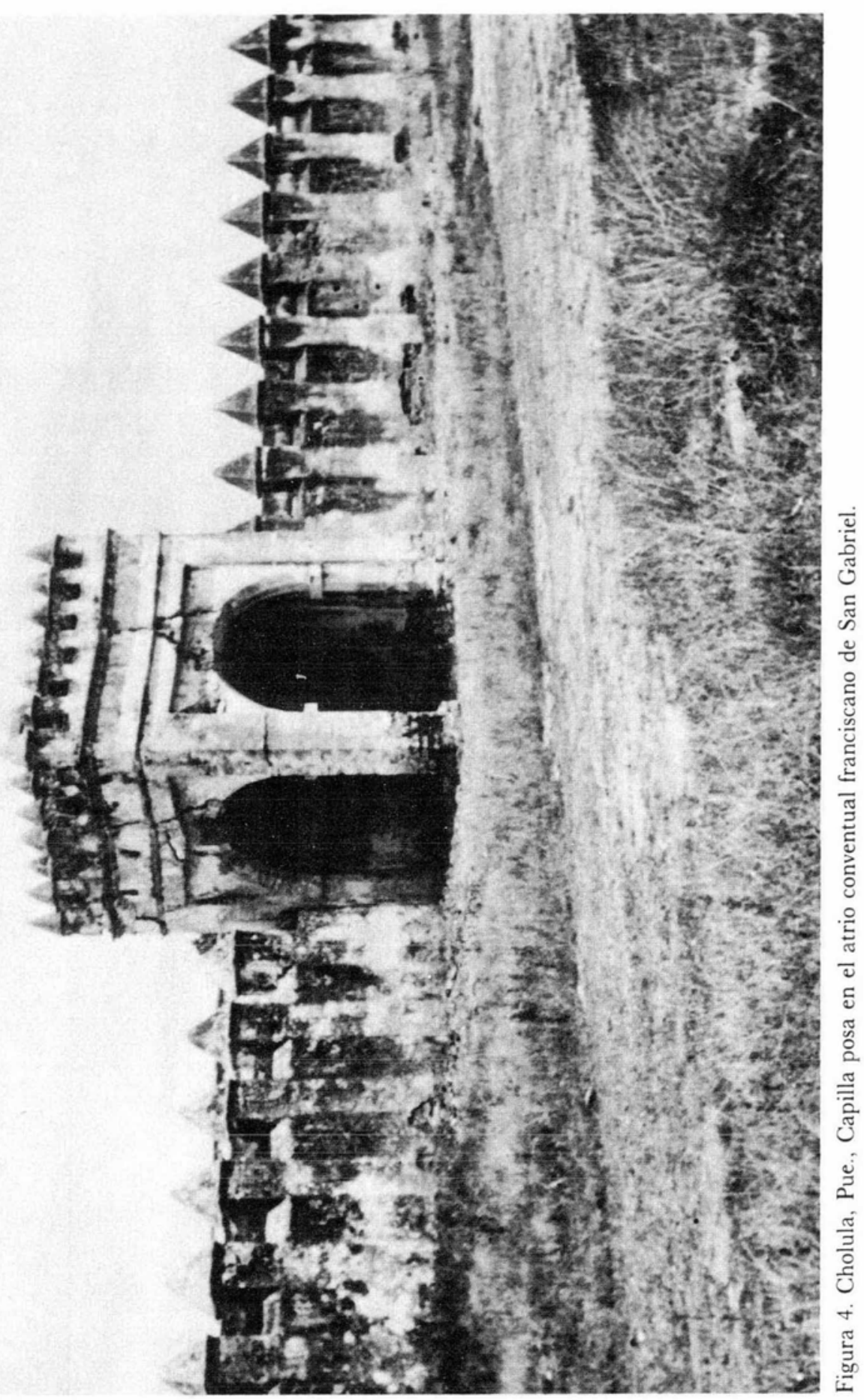


DOI: http://dx.doi.org/10.22201/iie.18703062e.1982.50\%20Tomo\%201.1137
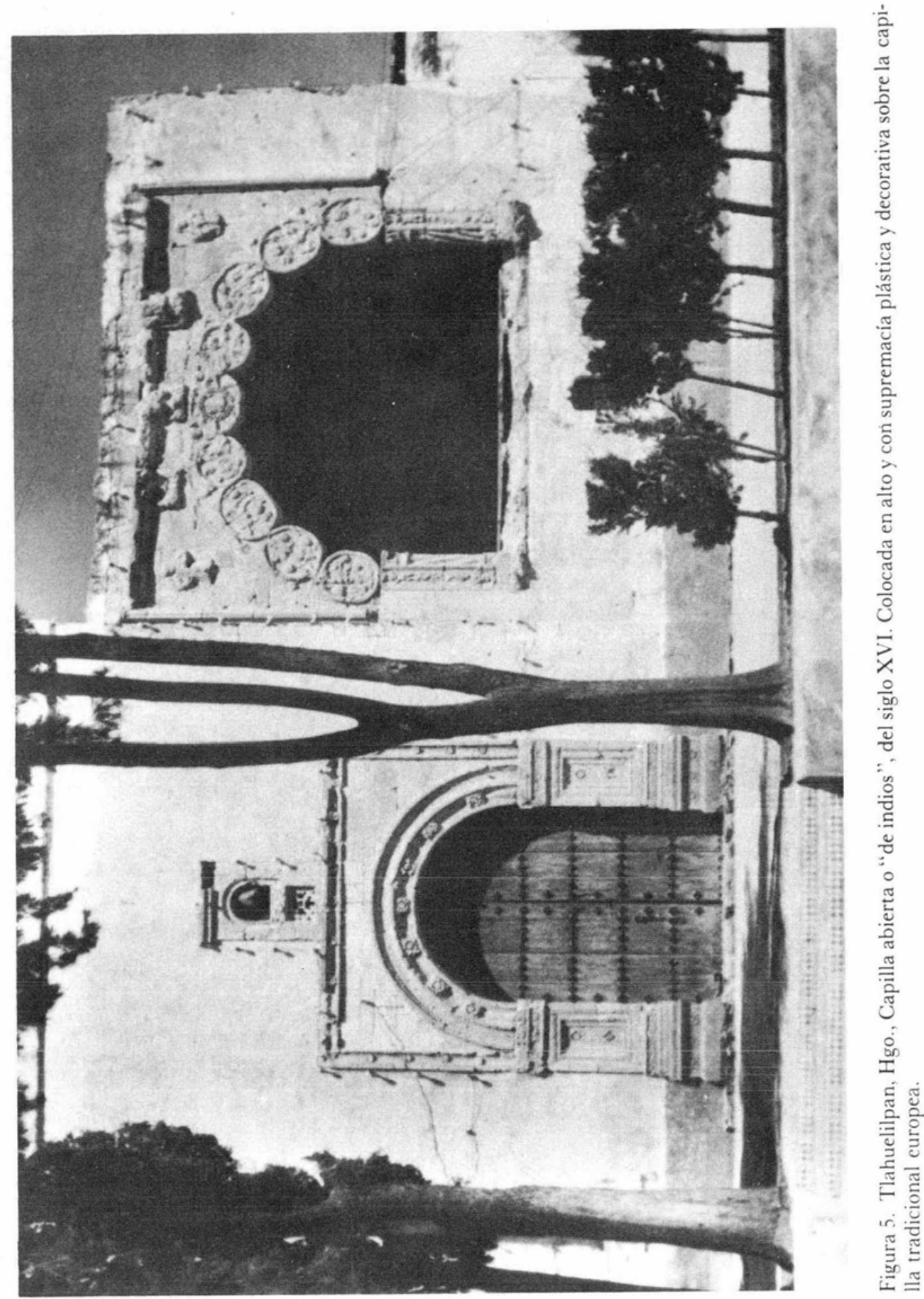


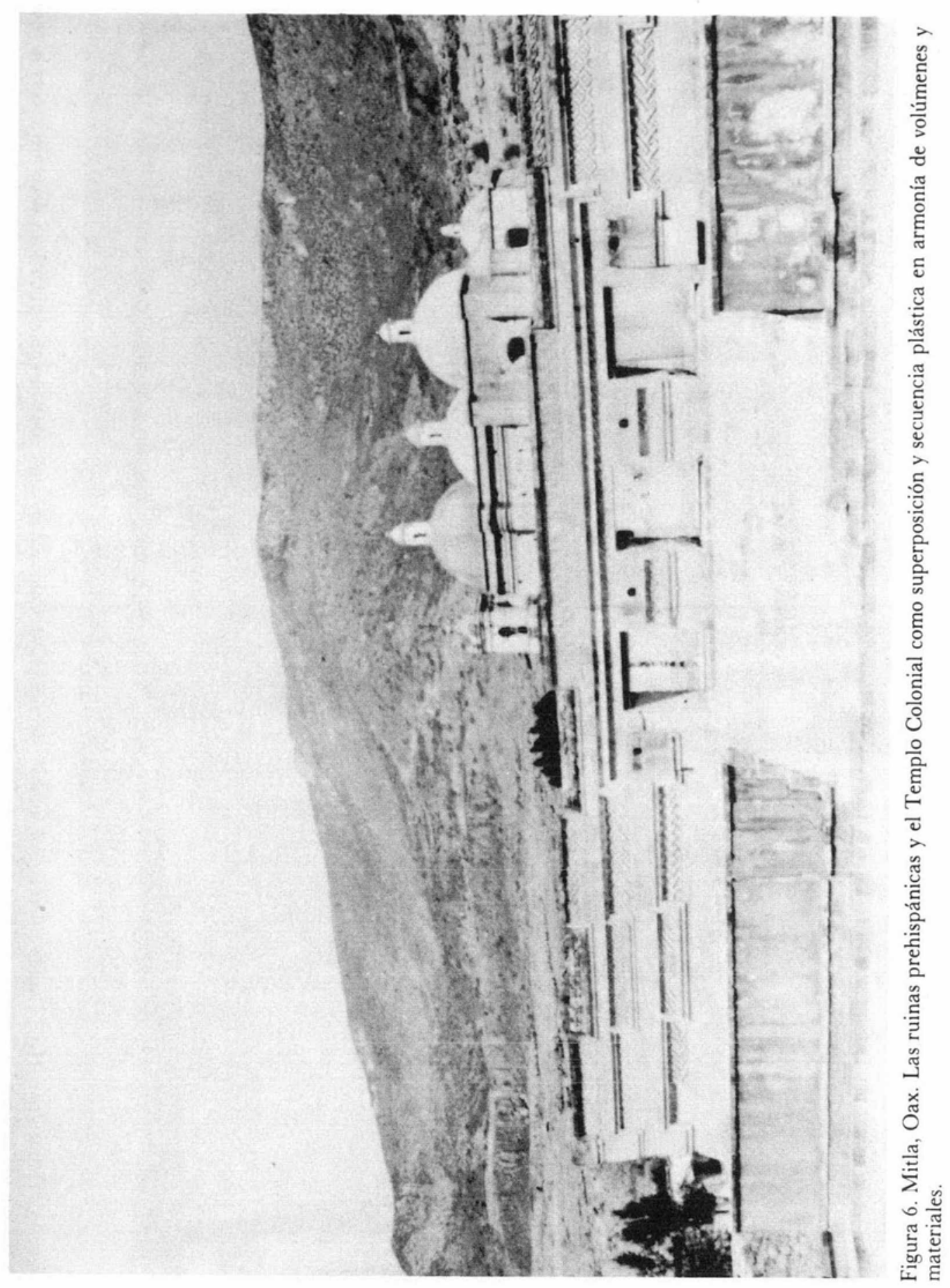




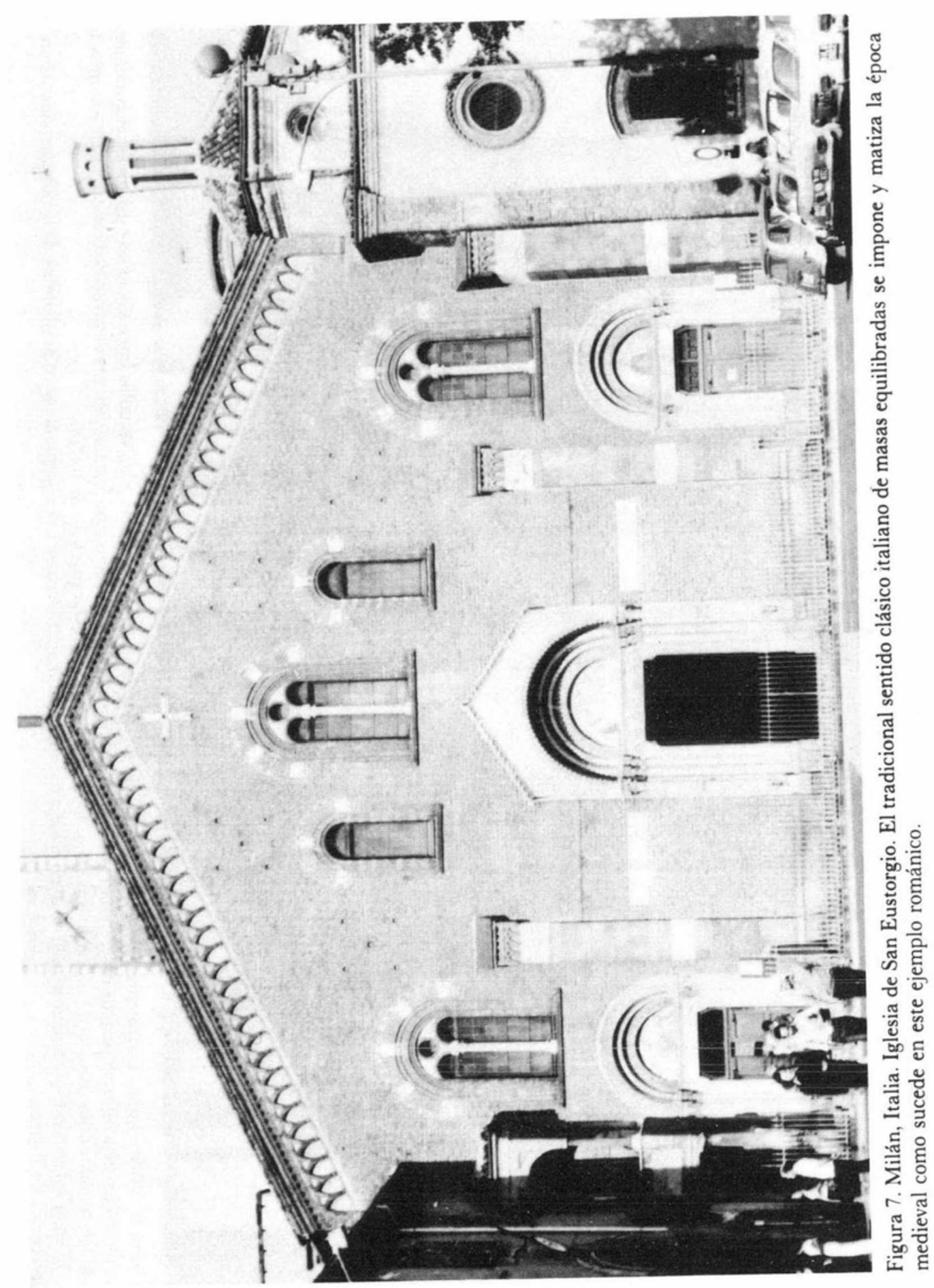




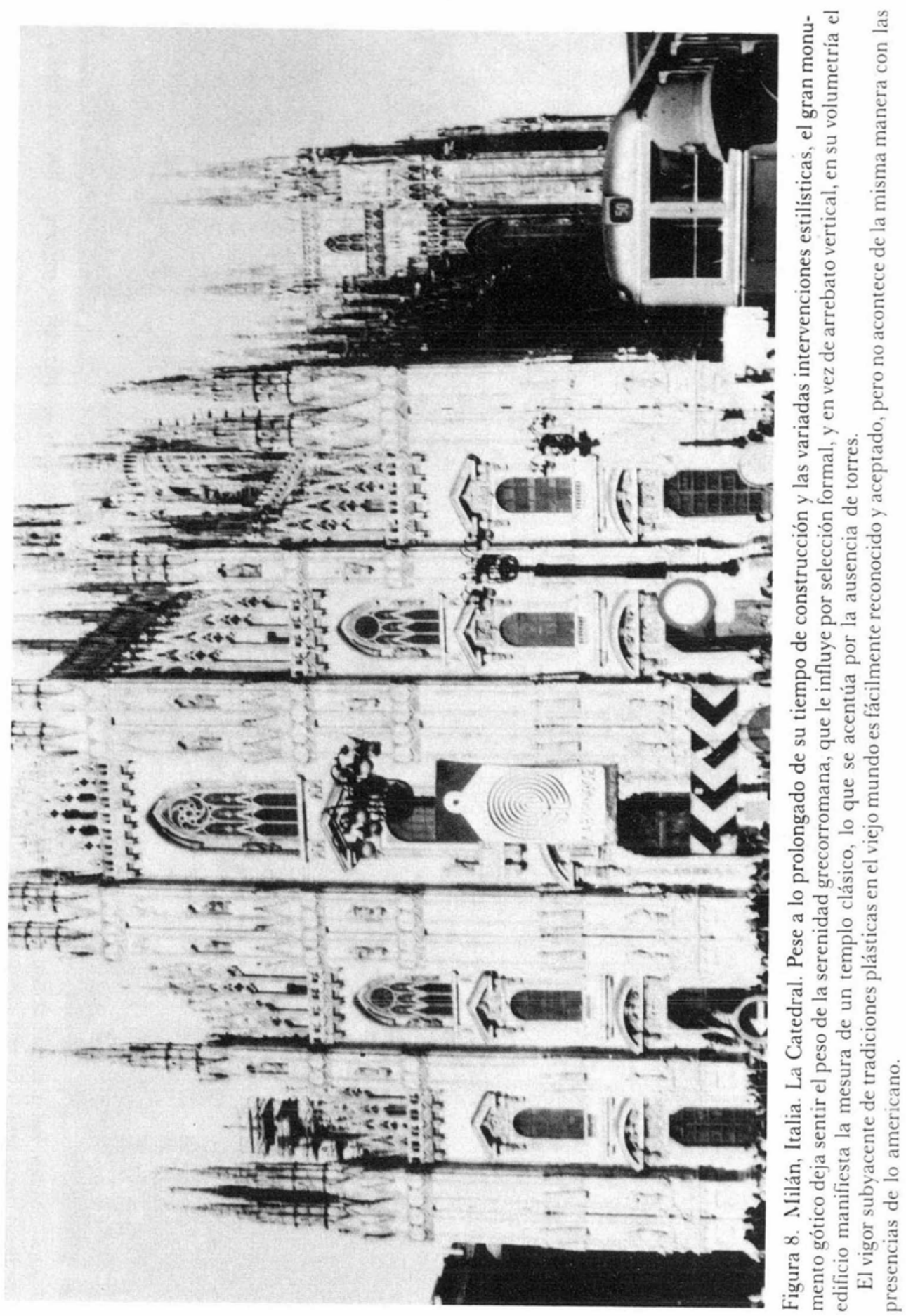


DOI: http://dx.doi.org/10.22201/iie.18703062e.1982.50\%20Tomo\%201.1137

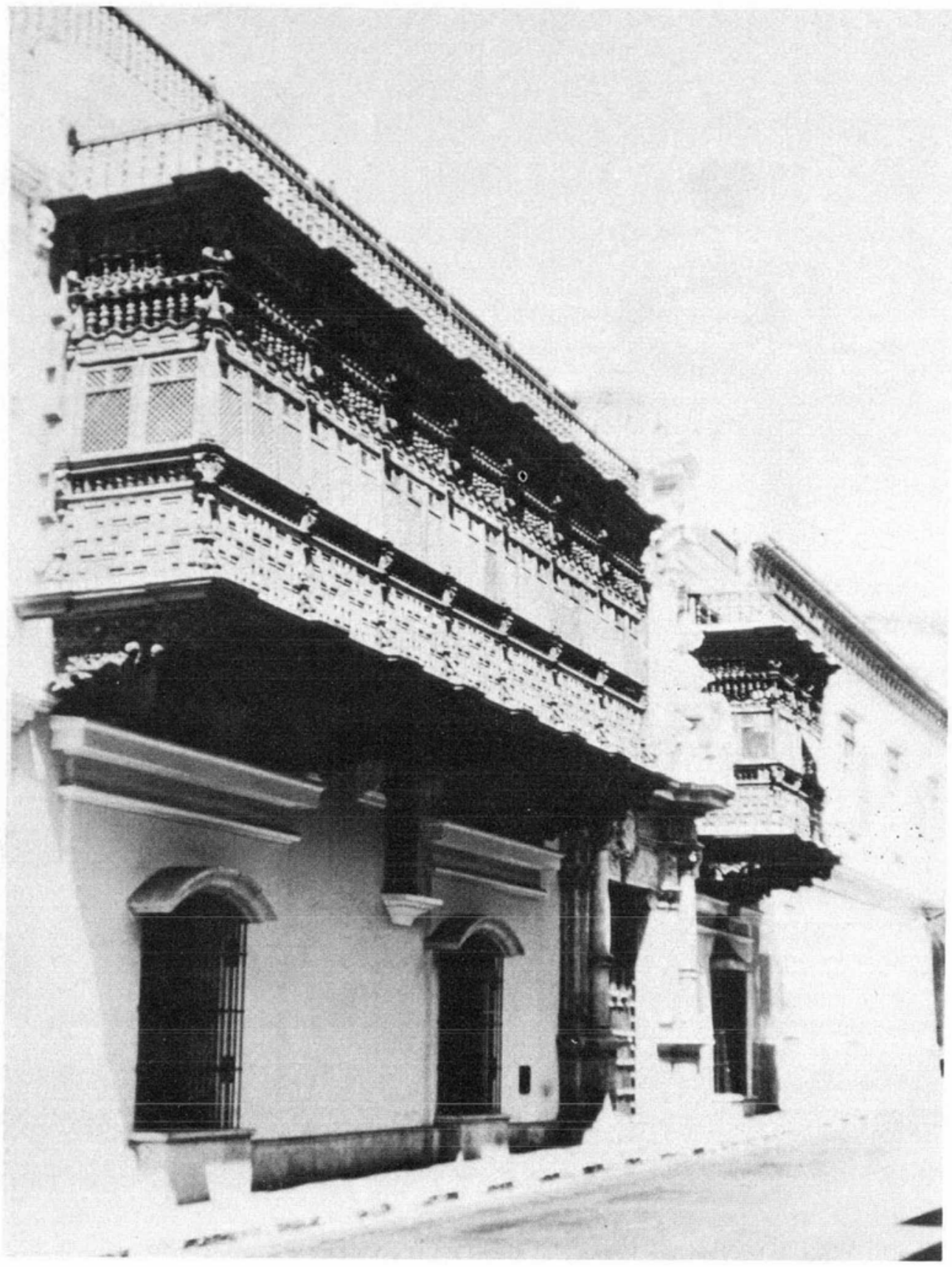

Figura 9. Lima. Palacio Torre Tagle. Siglo XVIII. Reminiscencias arábigas, "quinchas"y estuco son antecedentes y materiales que otorgan a Lima su peculiar gracia basada en la fragilidad de materiales y benevolencia de clima que le es natural. 


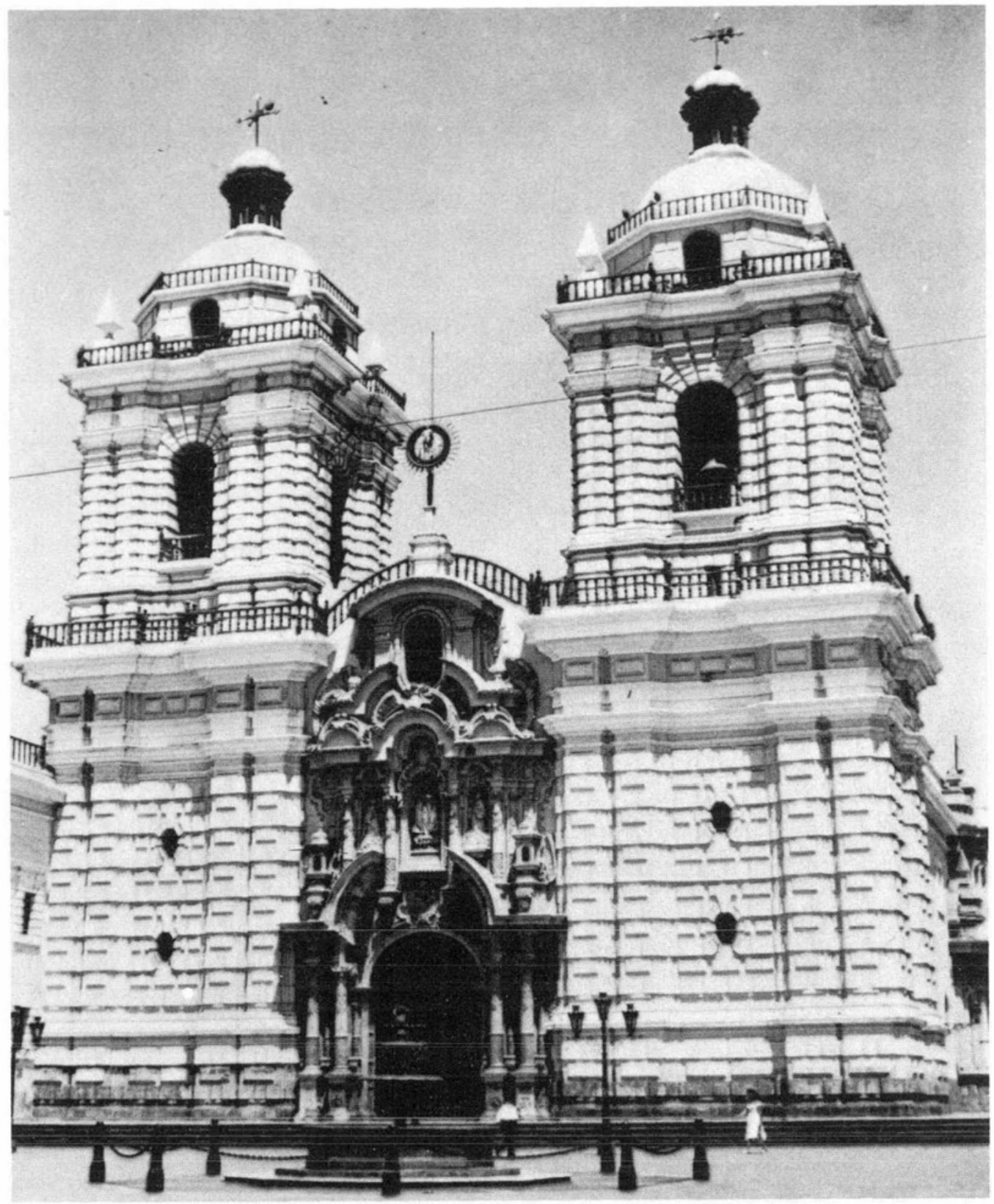

Figura 10. Lima. Iglesia de San Francisco. Siglos XVII y XVIII. Tan solo la portada en piedra y el ritmo claroscurista de los almohadillados manieristas que recubren tibia y suavemente núcleos leñosos de la estructura, nos indican cómo, la capital peruana, responde a una vocación más de ligereza antisísmica y de luminosidad polícroma costera de resequedad atmosférica, que a la fuerza constructiva y la severidad de la alta montaña. 


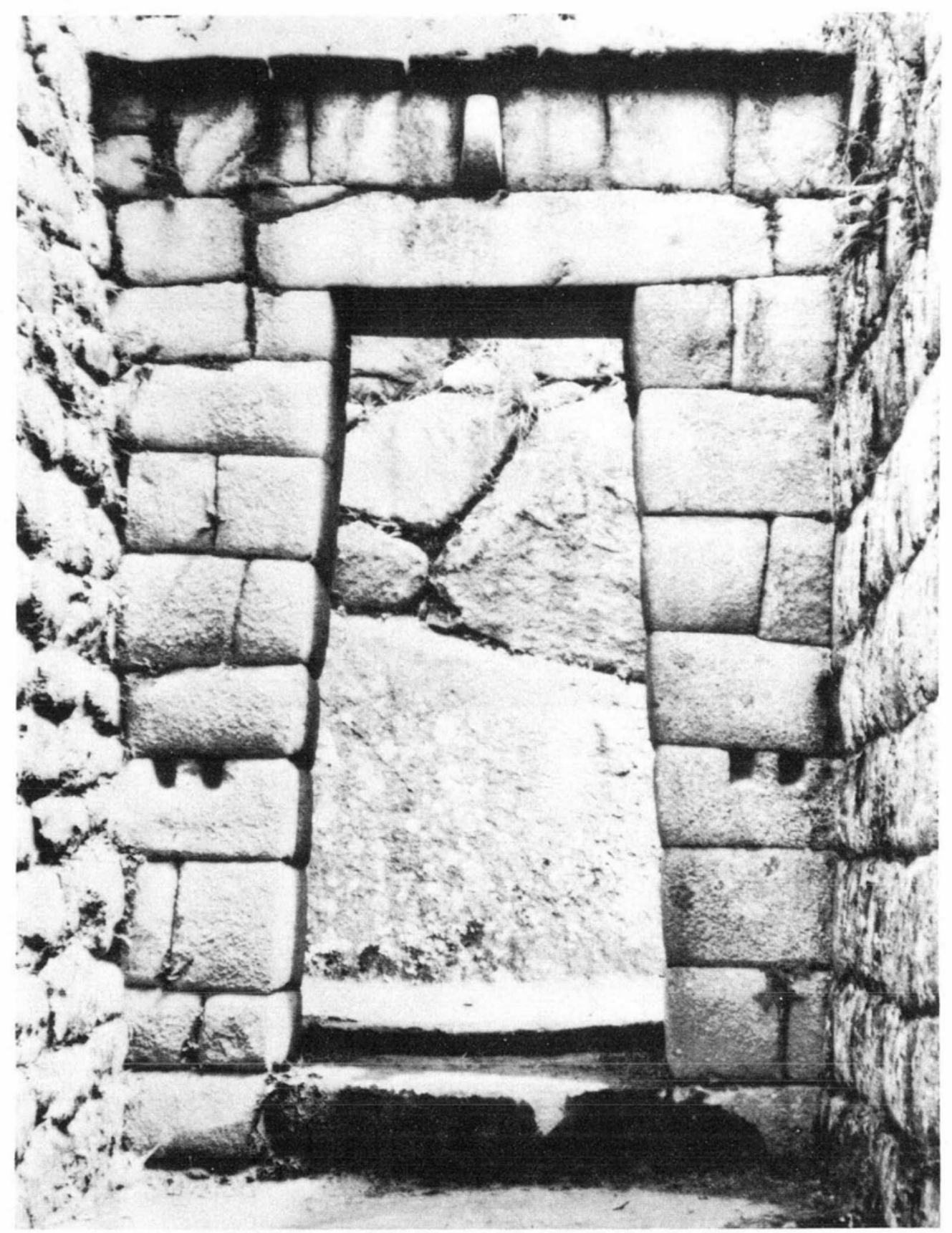

Figura 11. Macchu Picchu. Una de las peculiares y trapezoidales puerta ciclópeas de la región andina. Obsérvese el dintel monolítico. 
DOI: http://dx.doi.org/10.22201/iie.18703062e.1982.50\%20Tomo\%201.1137

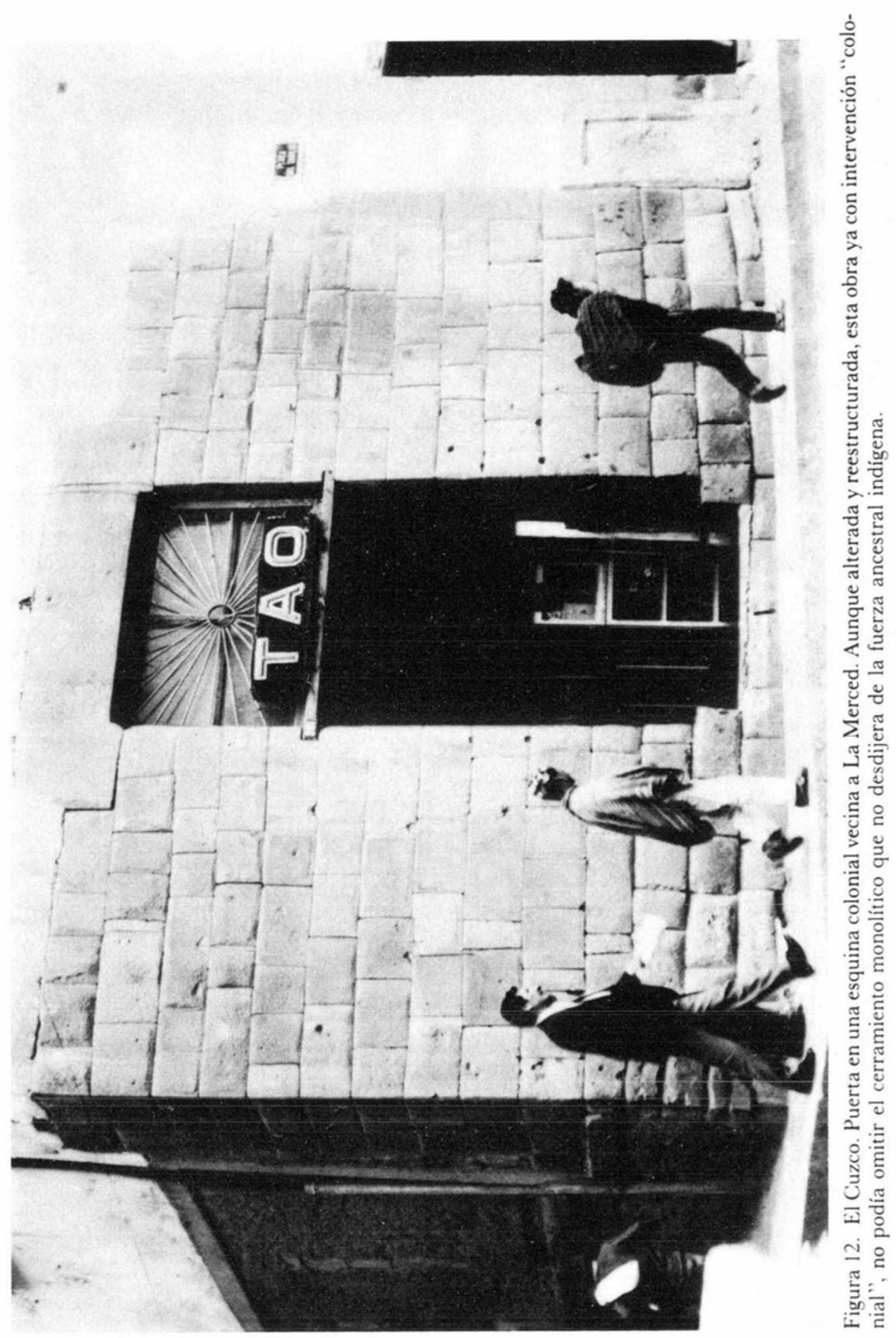




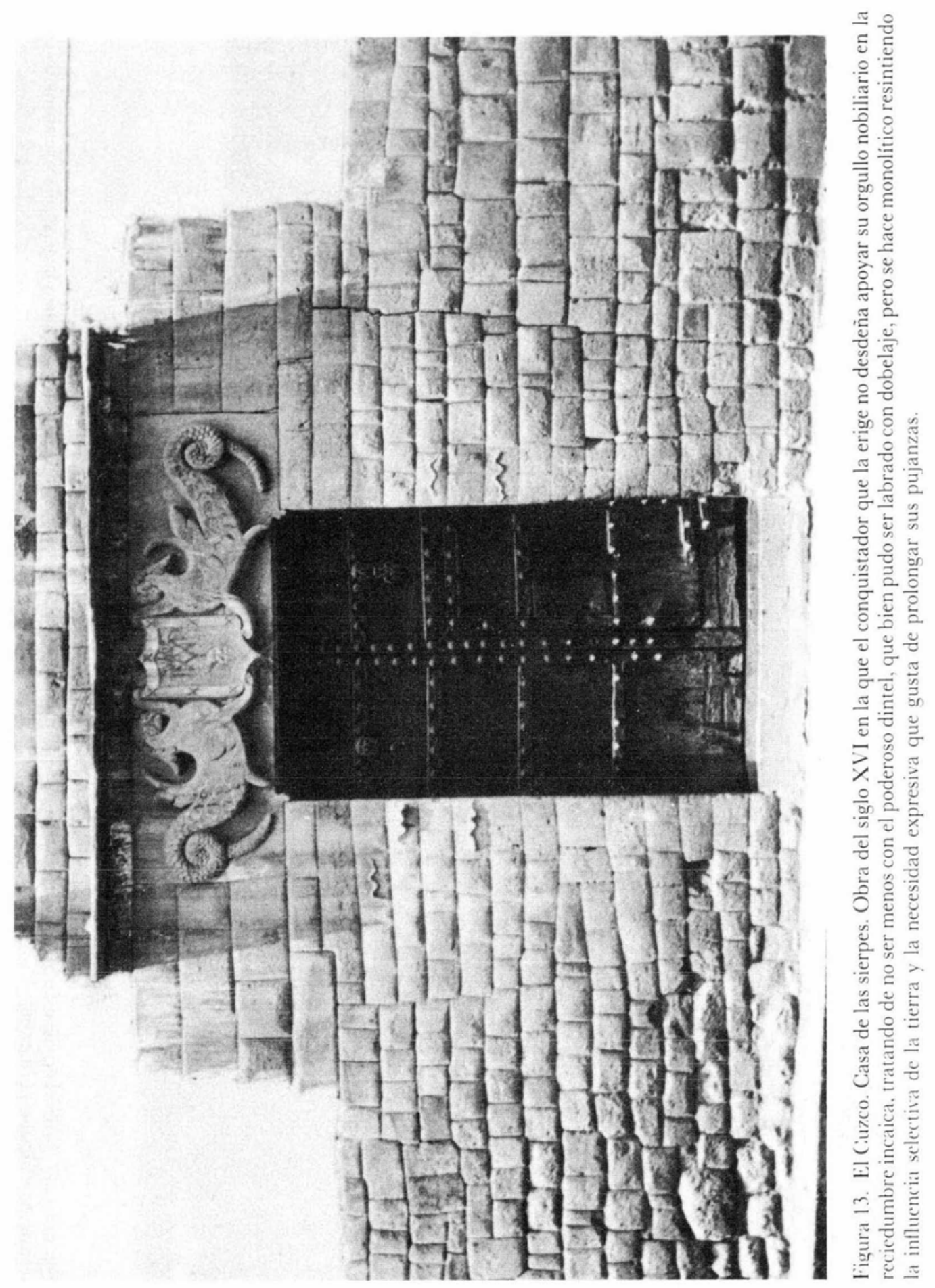




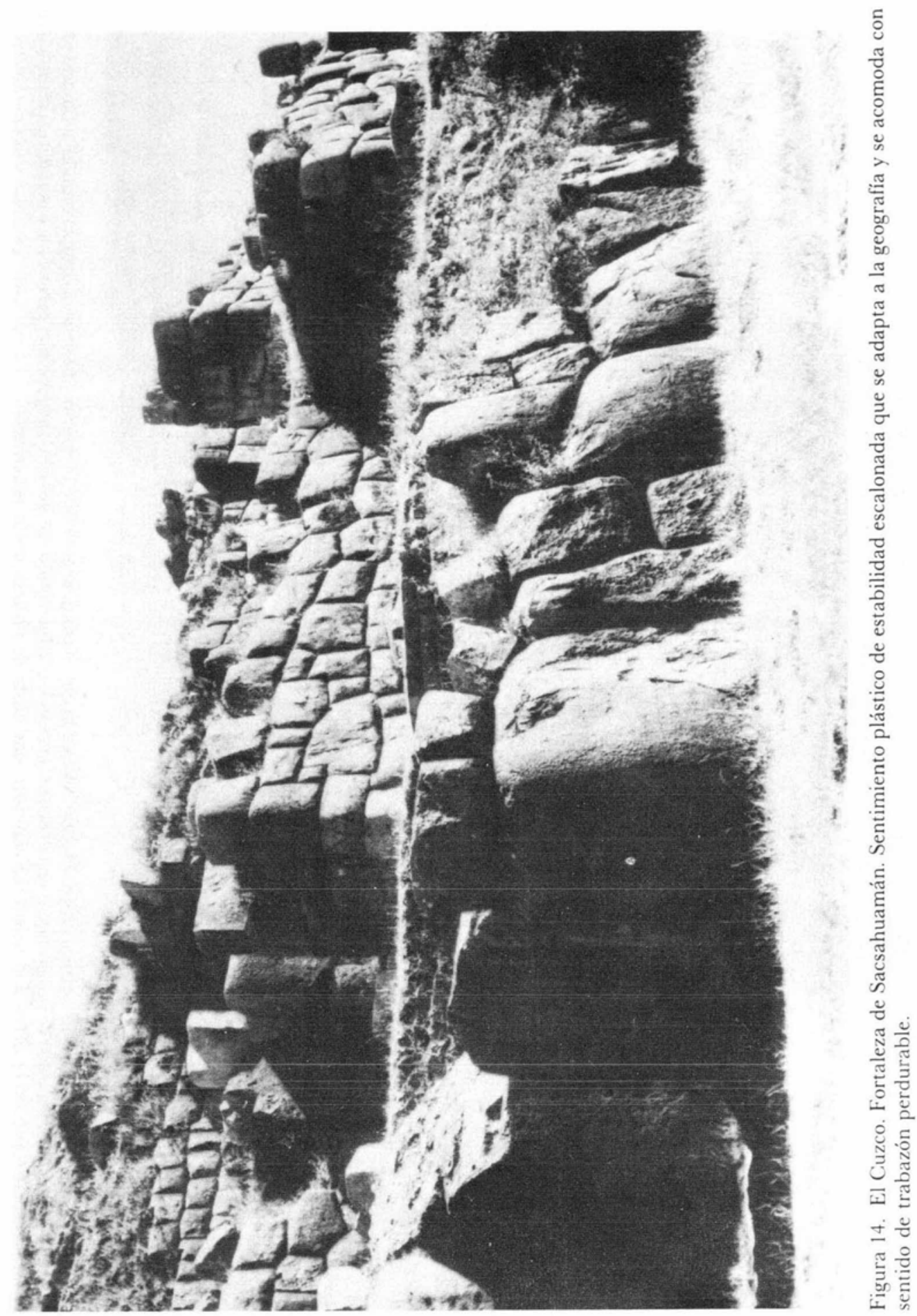




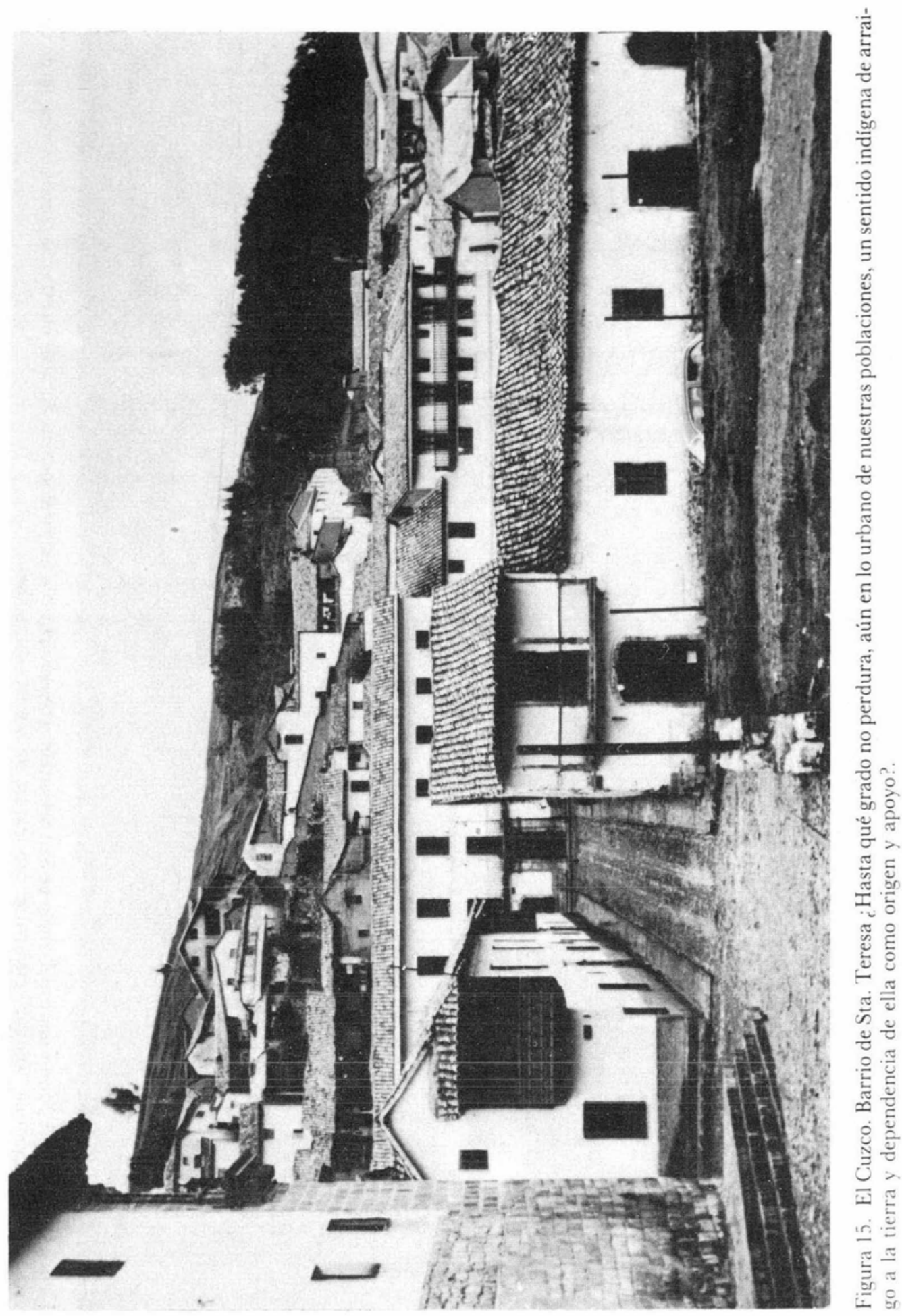




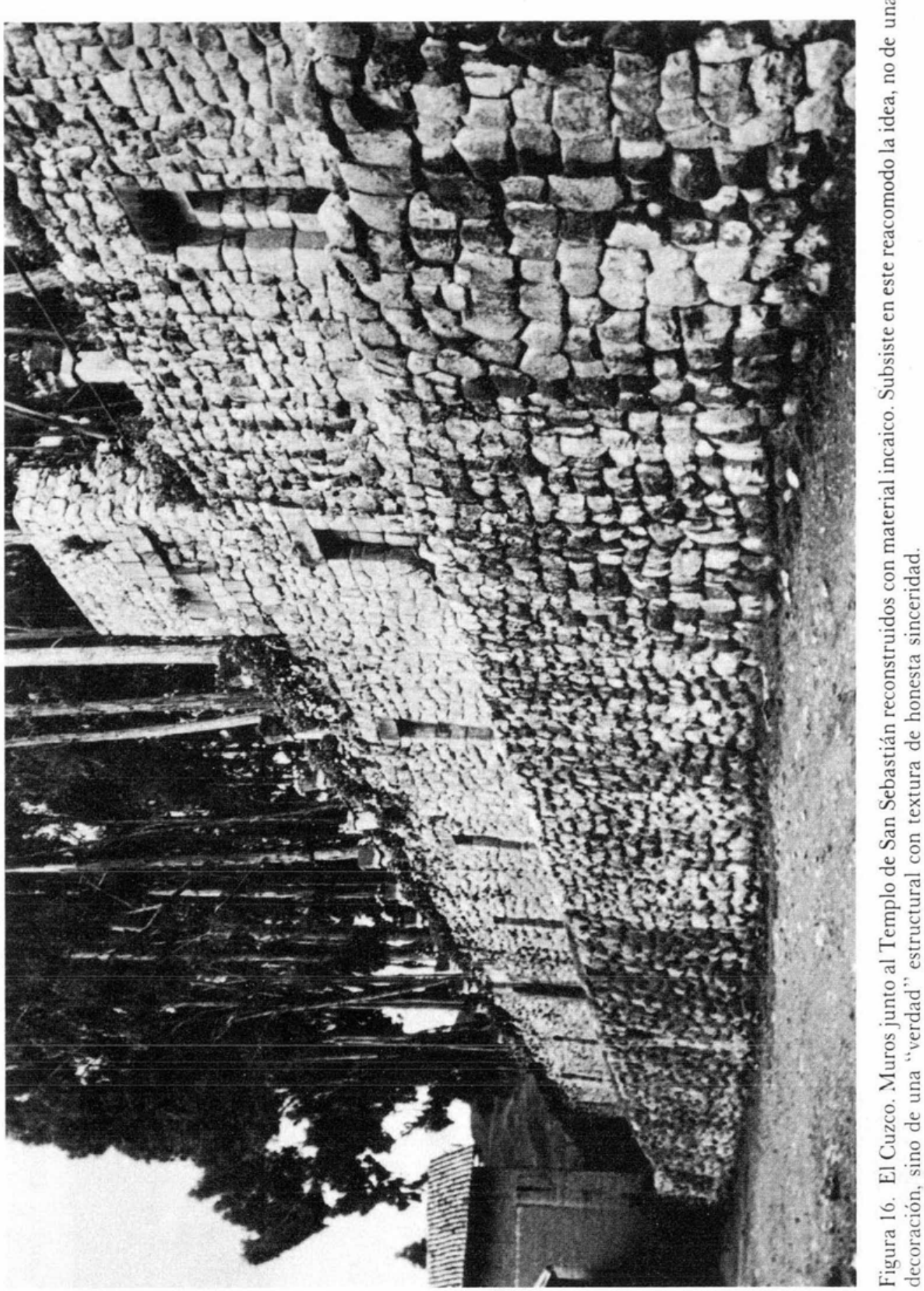




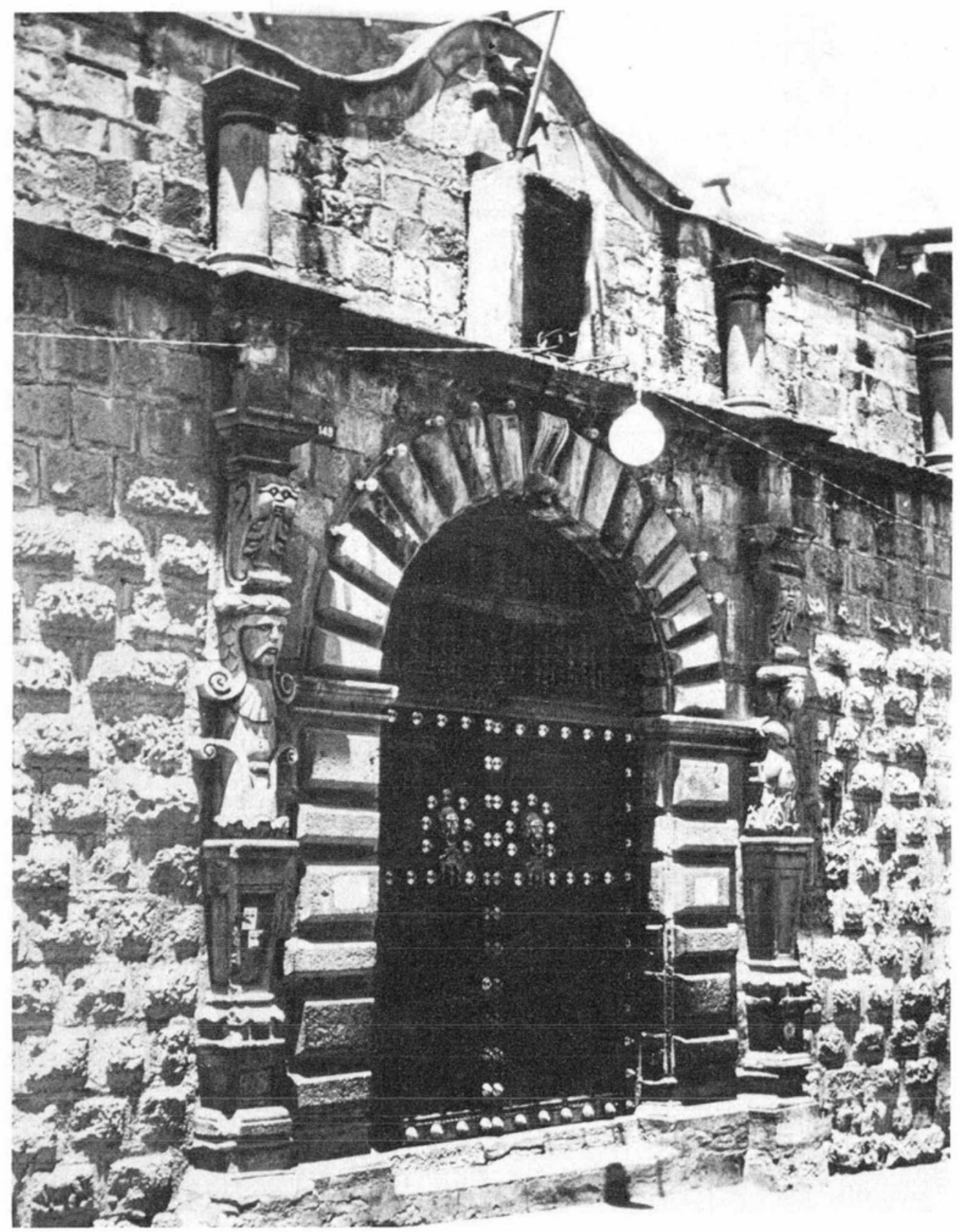

Figura 17. El Cuzco. Casa manierista del siglo XVII. Ni las jambas y arco almohadillado, ni las insólitas pilastras estípite (masculina y femenina), distraen del intenso claroscuro, "construido" como herencia y descendencia que solo en la región andina, y especificamente en El Cuzco, se podria dar como influencia que, no hurtada, tenía que manifestarse. 


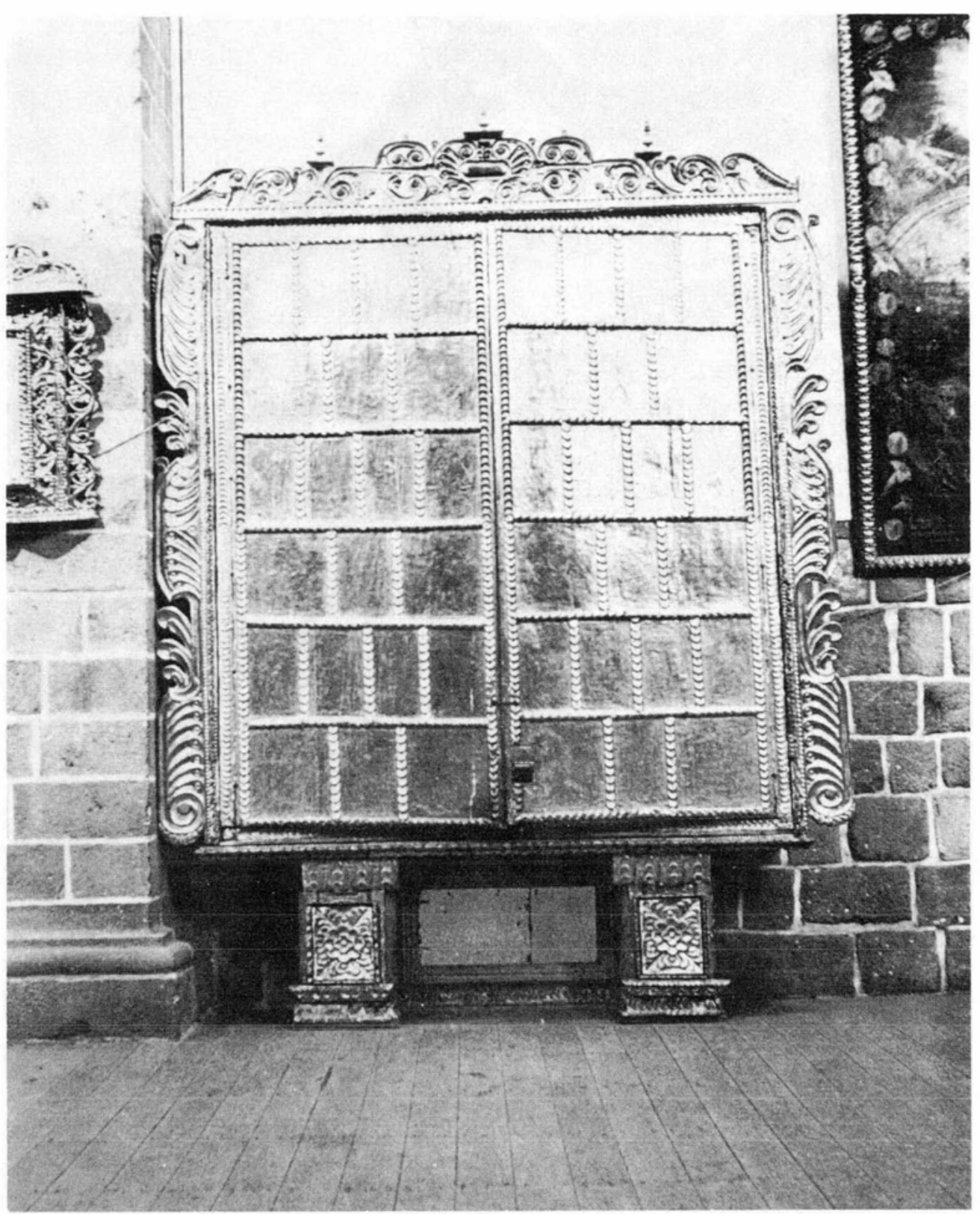

Figura 18. El Cuzco. Mueble en la iglesia de Sta. Catalina. Interesante ejemplo de cómo este objeto lígneo se incorpora a la arquitectura, desatendiendo el lógico sistema estructural de la carpintería a base de casetones regularmente ensamblados, y sus hojas, en cambio, más parecen un fragmento de mampostería pétrea como el que les sirve de fondo. ¿No parece obvia la influencia selectiva de fórmulas plásticas distintivas de la región?. 


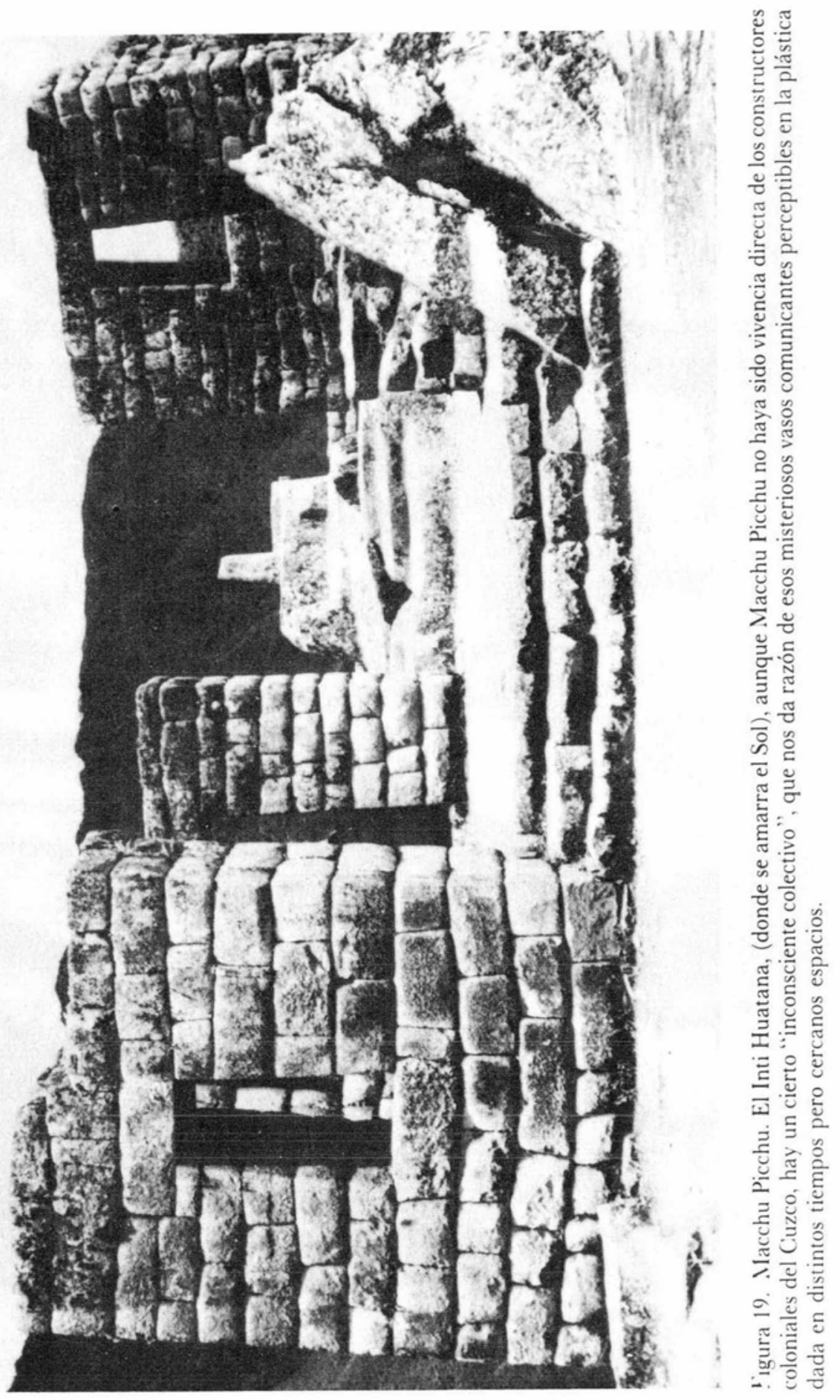




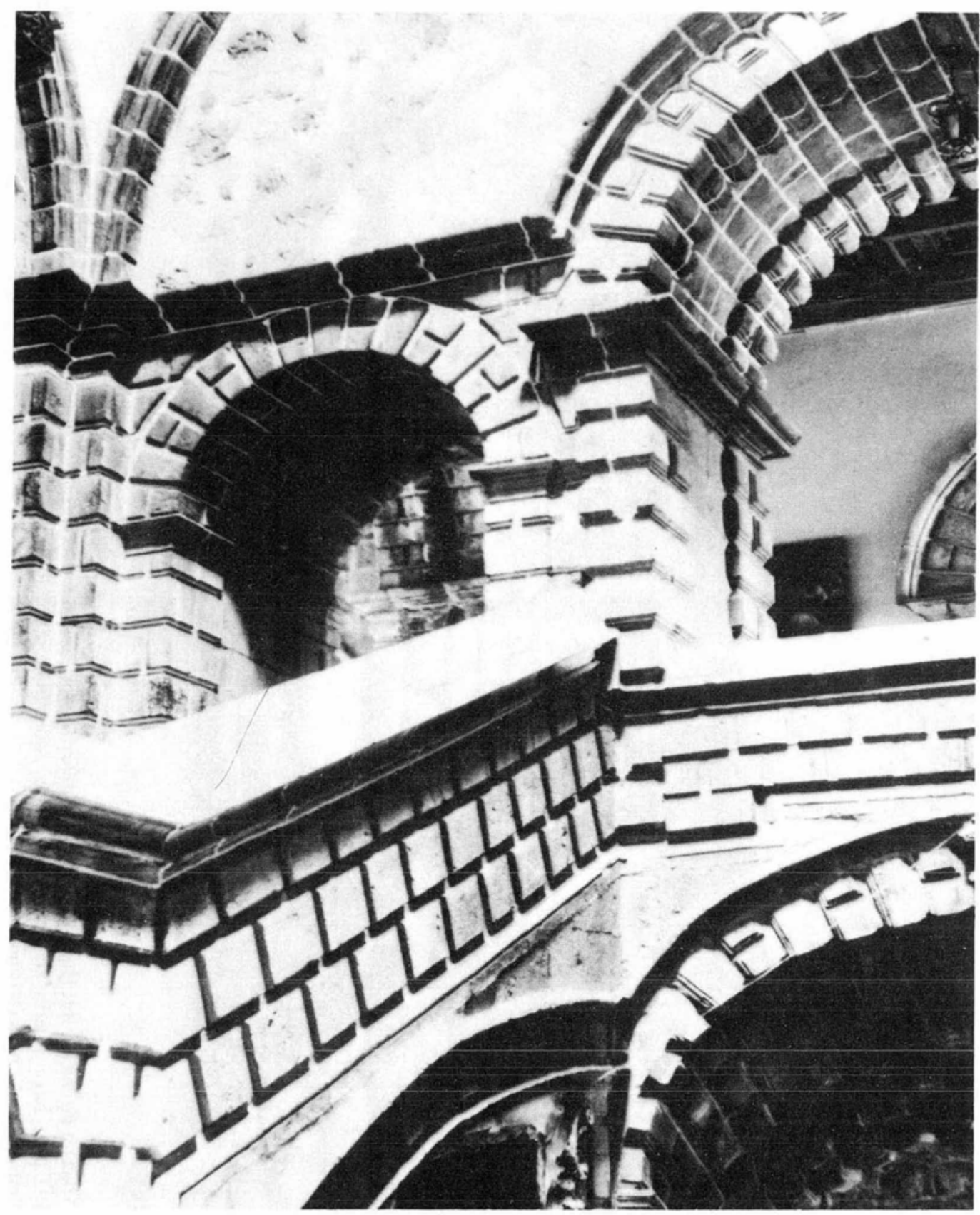

Figura 20. El Cuzco. Escalera del convento de La Merced. Obra del siglo XVII. Las piedras cristianizadas ya, con sus rampas, arcos y abovedados, no niegan ni desmienten un arrastre de ese "algo" que solo dan las raíces que profundamente penetran en la tierra. 


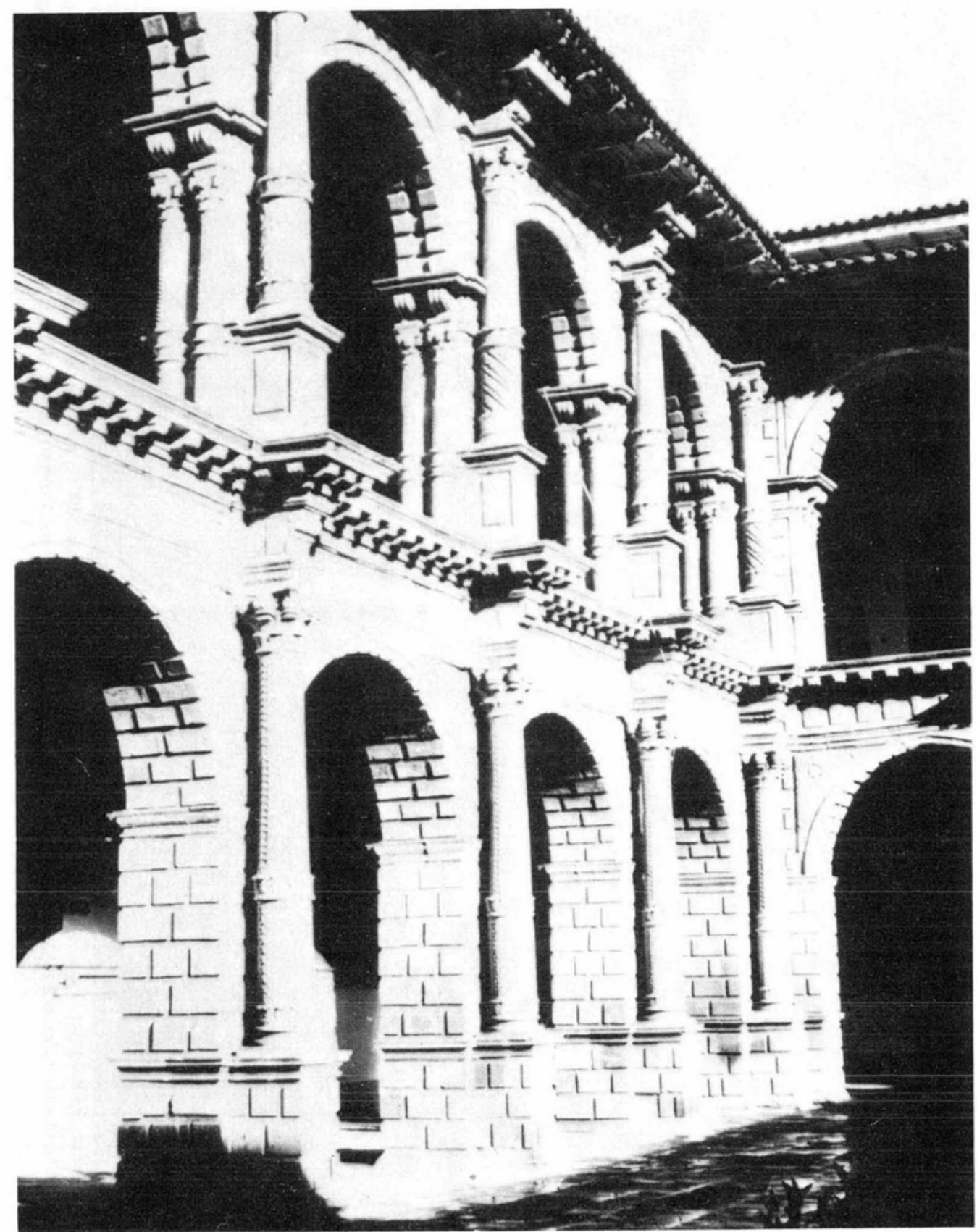

Figura 21. El Cuzco. Claustro conventual de La Merced. Siglo XVII. Considerado en su tiempo como "digno del rey de España", hay en esta alabanza, mestizaje de dignidades, pues tan para un rey hispánico, como lo podría ser para un monarca incaico. Indudable y hasta deseada realidad americana de conjunciones. 


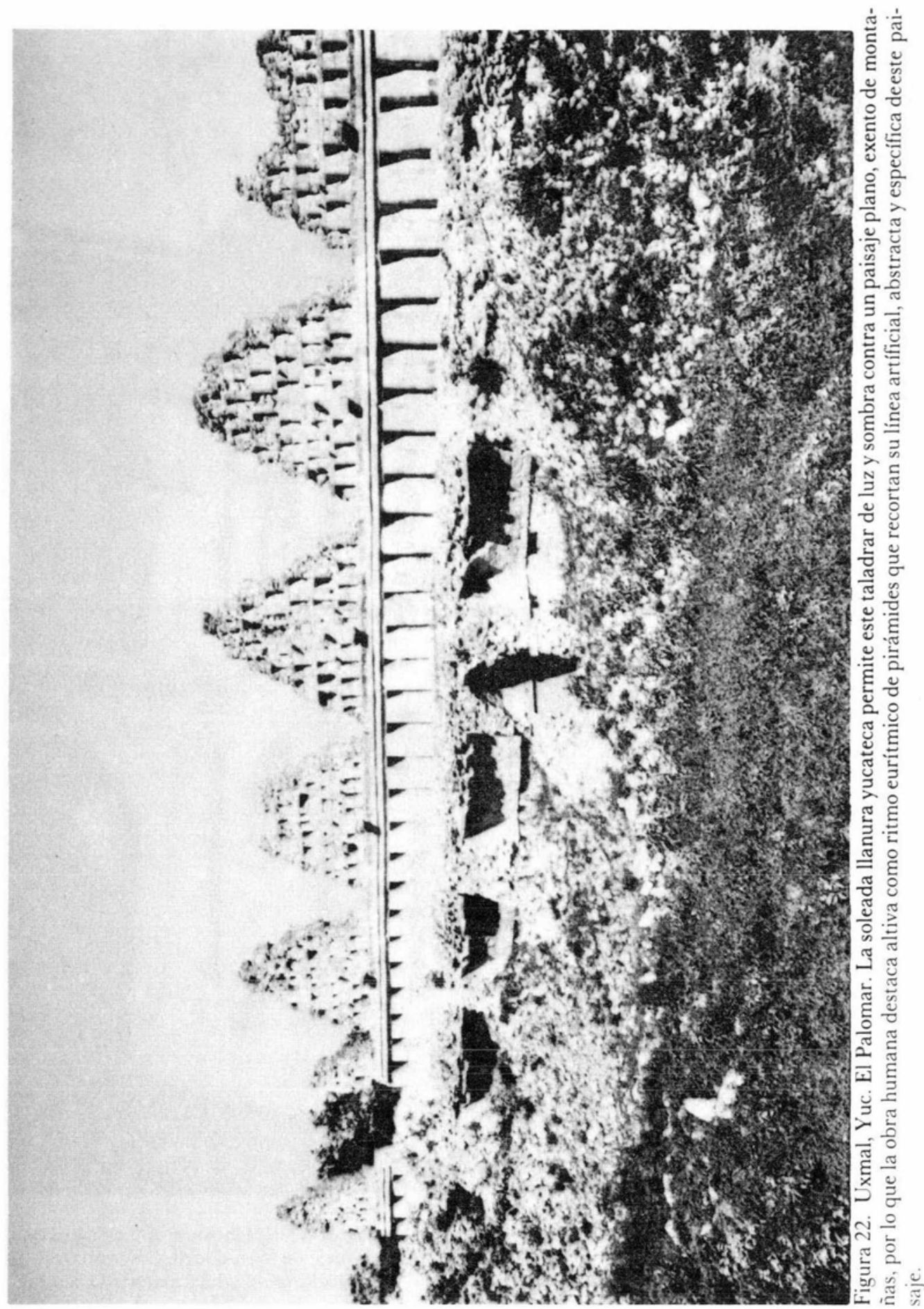



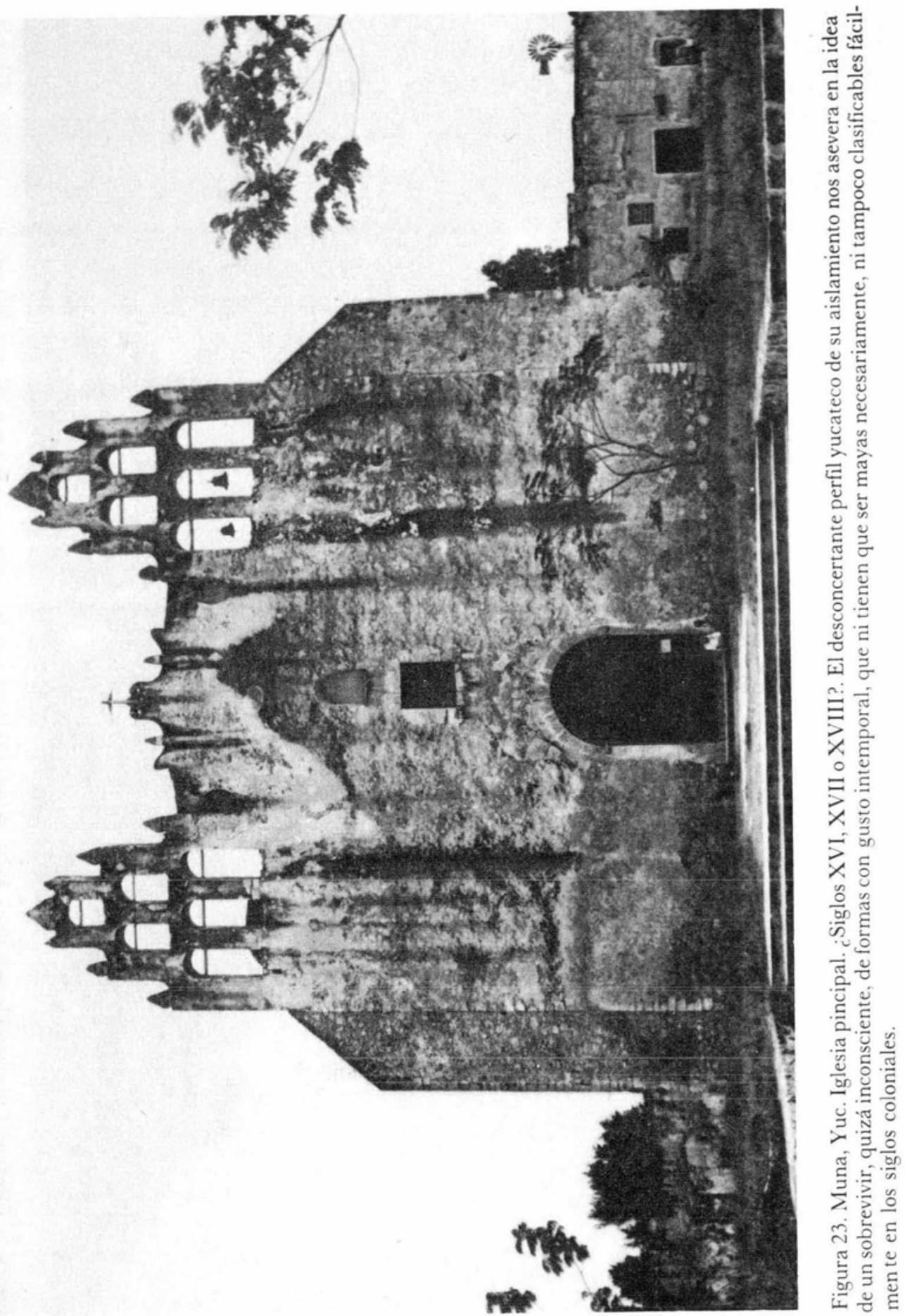


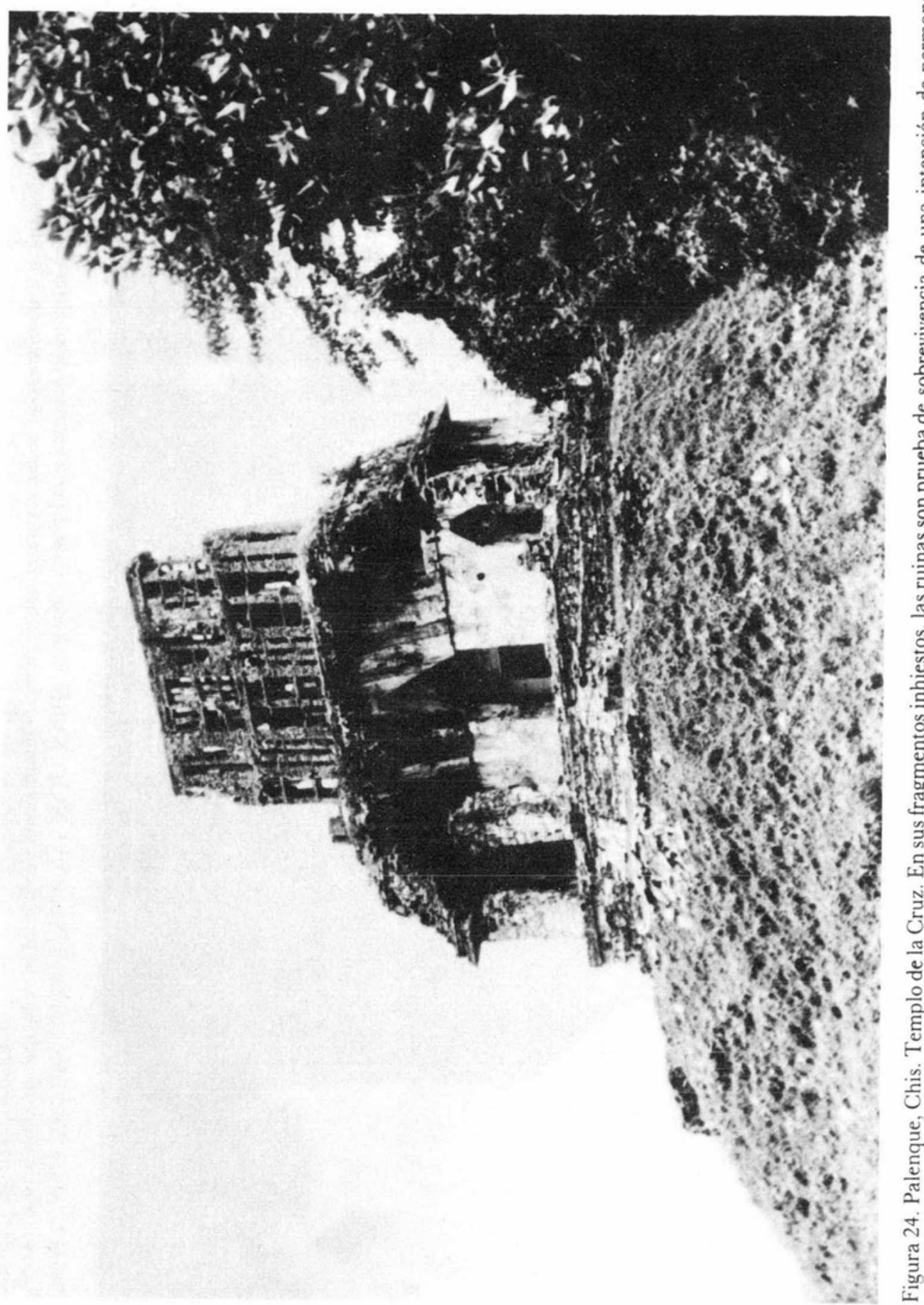




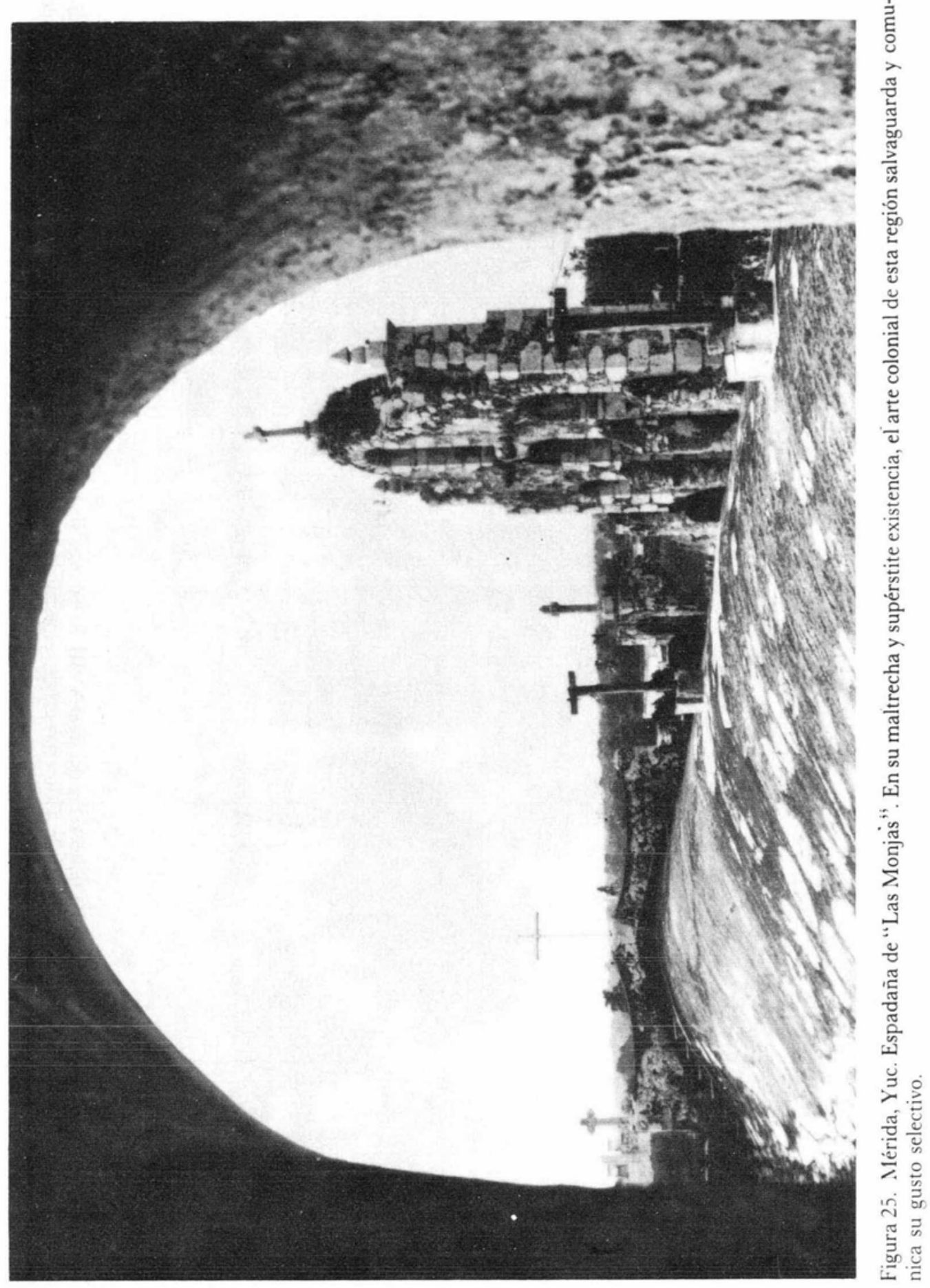




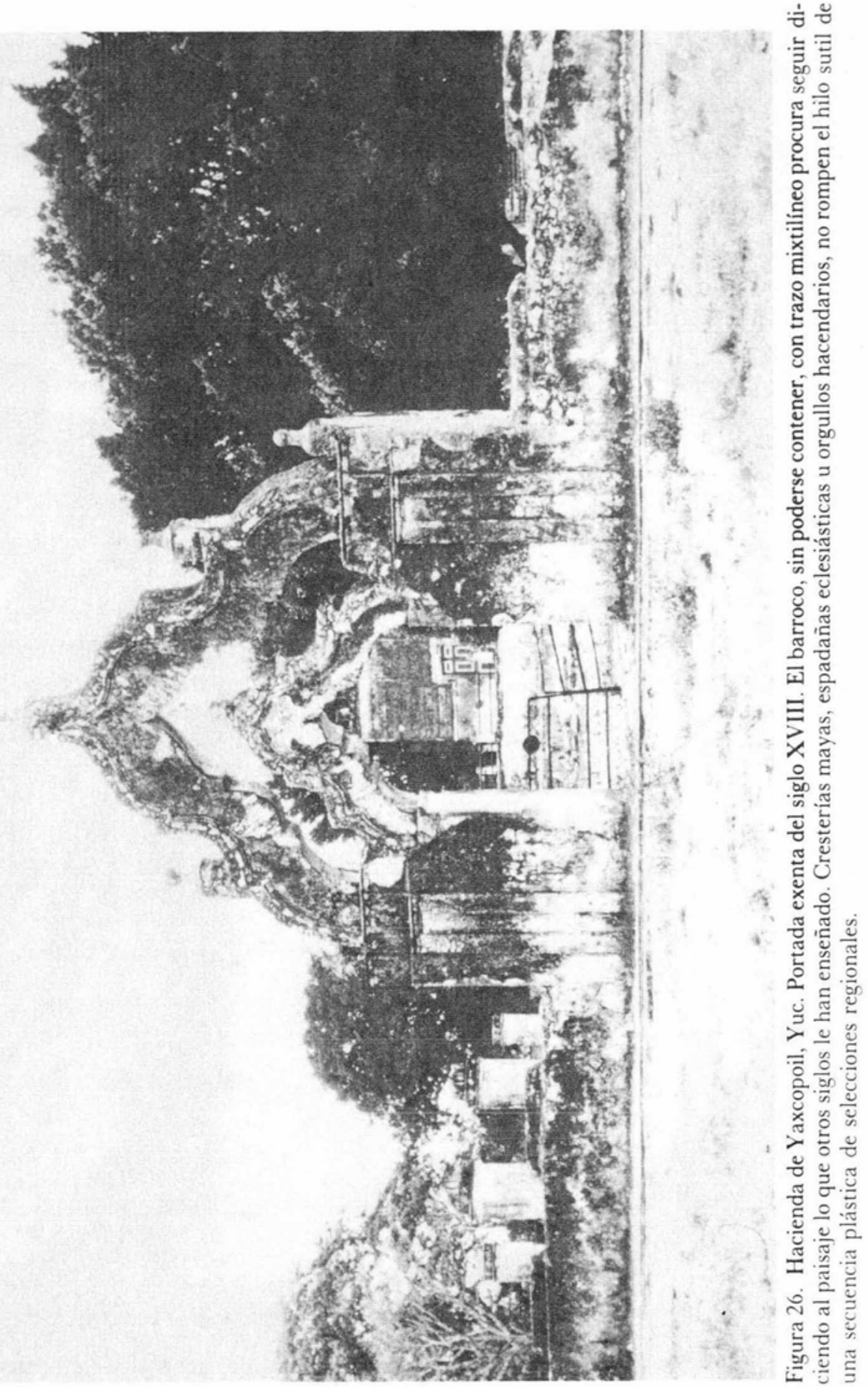




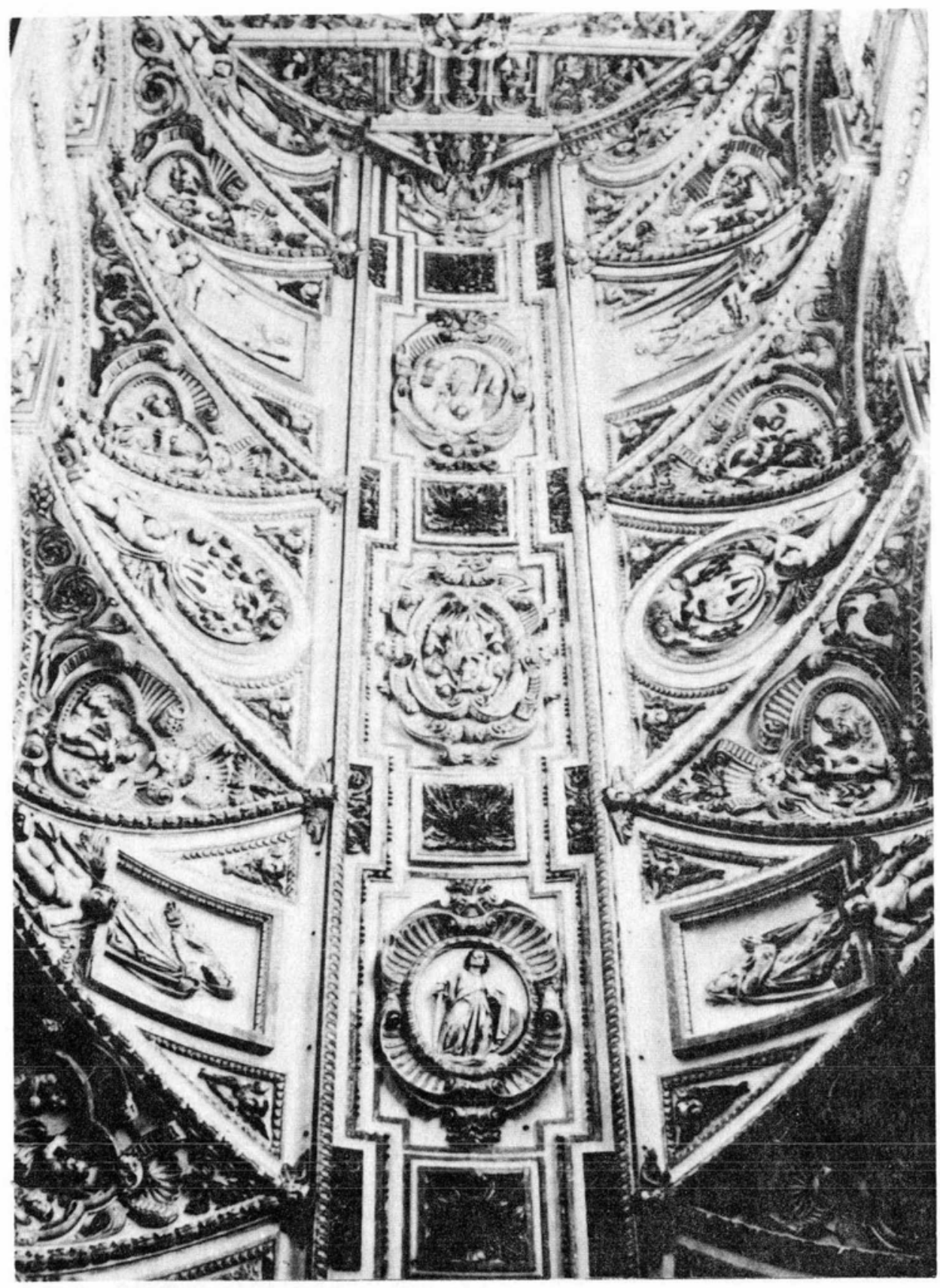

Figura 27. Córdoba, España. Decoración del siglo XVII en la bóveda mayor de la Catedral construida dentro de la Mezquita. Es indudable que al manierismo andaluz se le impuso la tradición arábiga, y por medio de las yeserías, acusa una didáctica y ejemplar manera de asimilación que “."selecciona" oportunamente lo que le era más afín. 


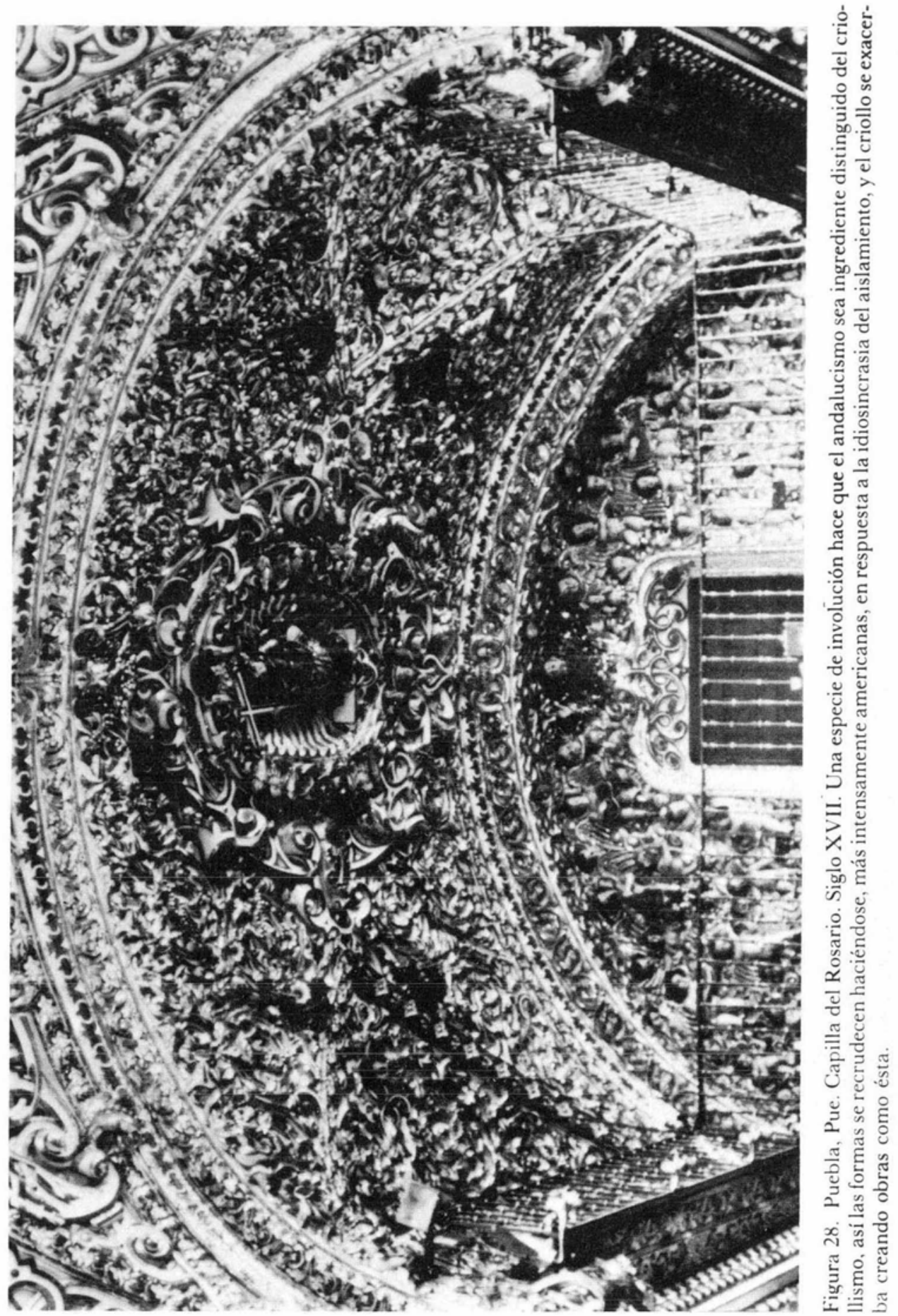




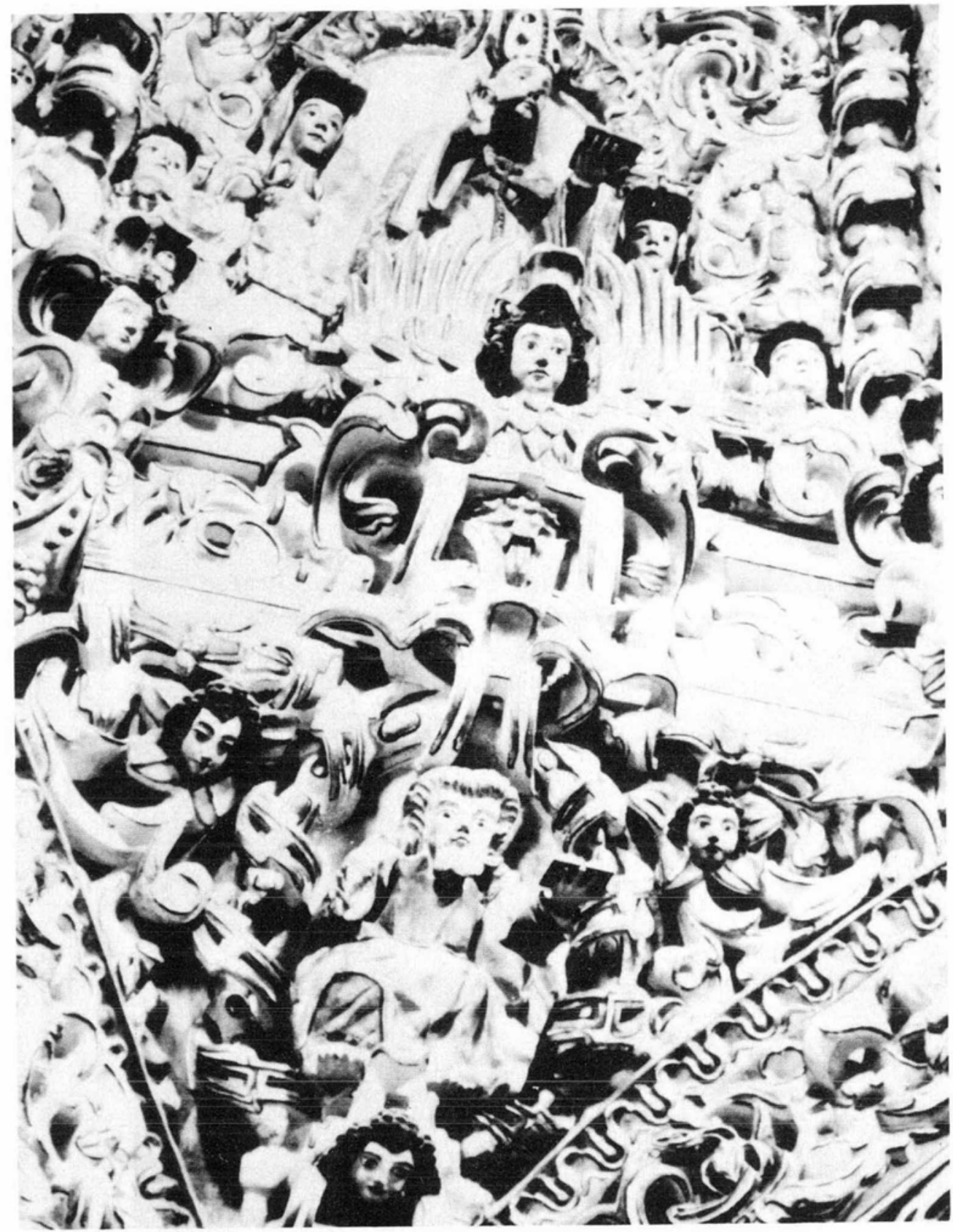

Figura 29. Sta. María Tonantzintla, Pue. Decoración interior de la cúpula. Siglo XVIII. El indígena, más que pretender copiar fielmente gusta de "contrahacer", como ya lo dijeron los cronistas desde el siglo XVI. Al hacerlo realiza su gusto interno, tanto que, lo que fue impuesto, se convierte, por decantación formal, en algo propio y esencial de su identidad. 

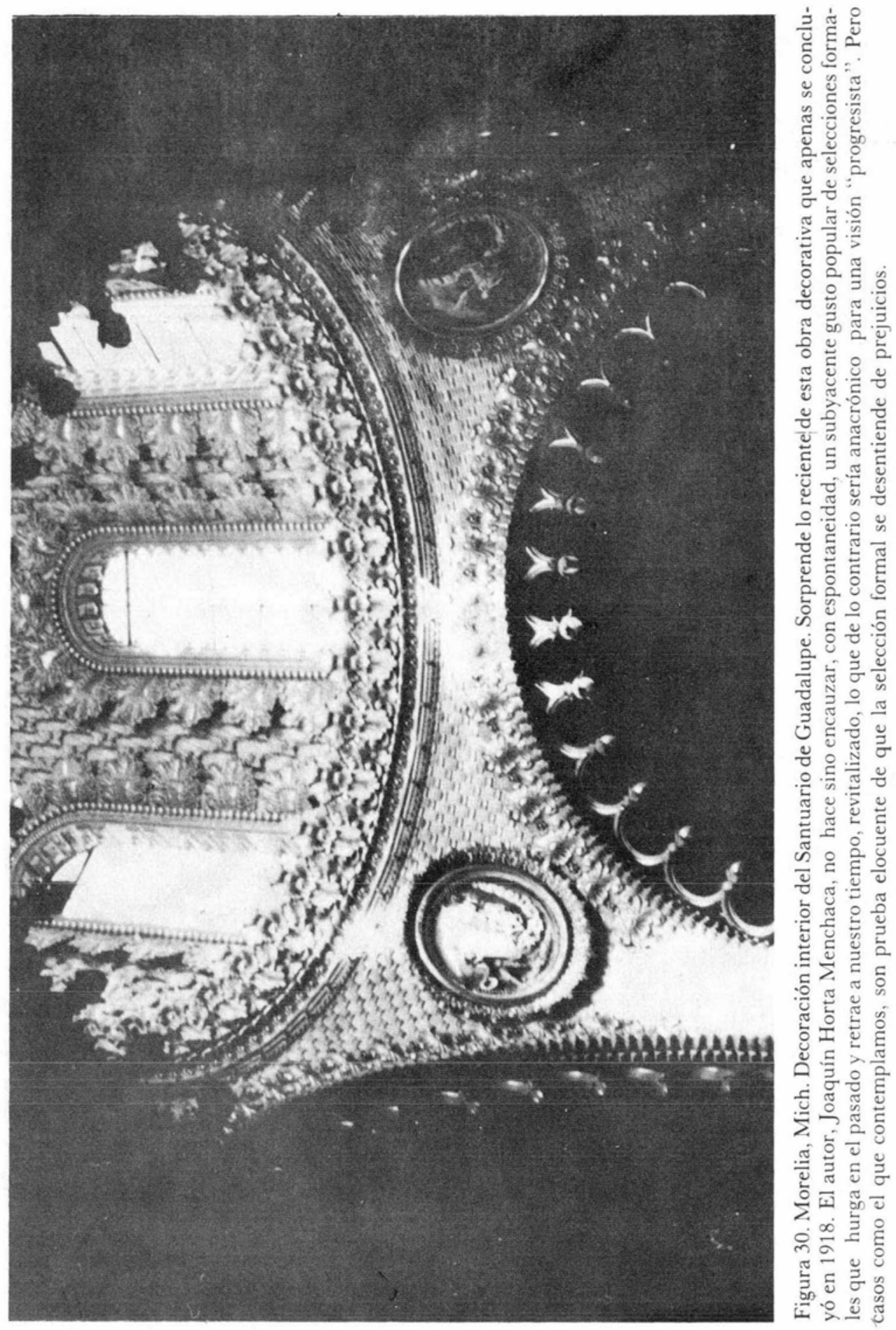
obras monográficas como la de Ilmar Luks, ${ }^{18}$ que aclaran y demuestran el grado de relación y dependencia tipológica entre lo europeo y lo americano, tampoco faltan opiniones severas y escépticas a los entusiasmos americanistas, que reconocen la importancia de estos estudios, pero se dejan llevar a su vez por equivalentes y contrarias emociones ideológicas. De esta corriente, útil por que obliga a reflexión y frena ilusorios nacionalismos, ha destacado por su tono polémico Graziano Gasparini, quien afirma que:

La retórica, como discurso persuasivo, es la actitud fundamental del pensamiento artístico del barroco; sin embargo, aunque represente el rasgo común de ese fenómeno cultural, actúa sobre los hombres no sólo para persuadirlos sino también para obligarlos a aceptar, sin posibilidad de discusión, lo que conviene a un determinado poder. Se implanta así una situación controlada en la cual las actividades culturales tienen una orientación claramente dirigida.

Es la situación de la América colonial. De tal suerte que el poder de persuación utilizado en forma opresiva, forzosamente produce expresiones diferentes y una propia especificidad. Tratar de captar lo específico es uno de los puntos más apasionantes para los que estudian el problema de la arquitectura colonial en América Latina. ${ }^{19}$

Ahora bien con todo lo antecitado, nos damos cuenta que el problema sigue oscuro y en discusión, pese a la amplitud con que se le ha tratado.

Lo que aquí queremos proponer, como quizá útil para una mejor comprensión del asunto, es un simple cambio de actitud, no negar la influencia del hombre americano en el arte colonial, pero sí tratar de entenderla con un giro de posición, verla no como una influencia directa, sino indirecta, no tanto considerarla como intención creativa sino como necesidad expresiva. En fin, que para entrar en materia, como una influencia por selección.

Queda claro que hay un hombre americano, sea indio, mestizo, criollo o mulato, que vive, sufre, goza espera y labora en estas tierras y que al contacto con la creación artística, tiene que expresarse, por obvia razón, dentro de sus limitaciones, pero que a la vez las condiciona, pues puede haber esclavitud socioeconómica pero es imposible el total dominio estético-espiritual, si tan de moda está hablar de éstas dicotomías. De tal manera el hombre americano pudo haber sido sujeto de explotación al máximo y en todos los aspectos que se quiera pero como hombre al fin, se expresó, y ésto dio lugar quizá a ese vigoroso barroco,

i* Luks, IImar Tiprologia de la pscullura decorativa hispánica en la arquitectura andina del siglo XVIII. Boletin del Centro de Investigaciones Históricas y Estéticas Núm. 17, Universidad Central de Veneruela, Ciaracas, 1973

19 Gasparini, Craziano Amérua, Barroos y Arquitectura Ernesto Armitano Editor. Caracas, 1972, $) 48$ 
compulsivo, desaforado, excéntrico; válvula de escape para las tensiones "coloniales".

Conforme a nuestra idea de la influencia por selección, no es posible apreciar un estilo o momento determinado de la historia del arte sin conocer el antecedente cultural del creador selector, ya sea individual o colectivo y aún dentro de aparentes autonomías estilísticas como sería el caso del Renacimiento, que se influye de lo grecorromano por selección y por esto no es arte clásico, sino renacentista, como en América el barroco no es europeo, pese a la gran dependencia que de ahí tiene, además de que América, influye por selección y de distinta manera en cada región, de aquí los matices locales

No podemos pasar por alto que este tipo de influencia, en algo o en mucho coincide con ideas como las de voluntad de forma y proyección sentimental que tan bien plantea Worringer, o la de los invariantes que propone Fernando Chueca Goitia, ${ }^{20}$ y hasta podemos relacionarla con ciertos argumentos científicos de la sensibilidad, como lo argumentó Aldous Huxley al relatar su experiencia con la mescalina, el principio activo del peyotl, cactu de tan importante tradición mítico-religiosa entre los indígenas de México, así escribe que:

al reflexionar sobre mi experiencia, me senti de acuerdo con el eminente filósofo de Cambridge doctor C. D. Broad en que 'haríamos bien en considerar con más seriedad que hasta ahora el tipo de teoría que Bergson presentó en relación con la memoria y la percepción de los sentidos'. Según estas ideas, la función del cerebro, el sistema nervioso y los órganos sensoriales es precisamente eliminativa, no productiva. Cada persona, en cada momento, es capaz de recordar cuanto le ha sucedido y de percibir cuanto está sucediendo en cualquier parte del universo. La función del cerebro y del sistema nervioso es protegernos, impedir que quedemos abrumados y confundidos por esta masa de conocimientos en gran parte inútiles y sin importancia, dejando fuera la mayor parte de lo que de otro modo percibiríamos o recordaríamos en cualquier momento y admitiendo únicamente la muy reducida y especial selección que tiene probabilidades de sernos prácticamente útil. Conforme a esta teoría, cada uno de nosotros es potencialmente Inteligencia Libre "Pero, en la medida en que somos animales, lo que nos importa es sobrevivir a toda costa. ${ }^{21}$

Sin que estas ideas puedan aplicarse directamente a nuestro problema artístico, sí es posible que pueda haber un trasfondo sicológico indirecto, de-

\footnotetext{
${ }^{20}$ Chueca Goitia, Fernando "Invariantes en la arquitectura Hispanoamericana" Revusta de Occidente No. 38, Madrid, mayo 1960

${ }^{21}$ Huxley, Aldous Las puertas de la percepción y Cielo e infierno Trad de Miguel de Hernani. Editorial Sudamericana, séptima edición Buenos Aires, 1975, p 22
} 
fensivo de la libertad e identidad, tanto personal como colectiva, en este seleccionar lo considerado útil-estético

Como antes apuntamos, quiero insistir que, para mejor entender la influencia americana en su arte colonial, es conveniente considerarla no como influencia formal directa, que es como en la mayoría de los casos se la ha buscado, sino que se vea desde el otro lado del lente como indere ta por selección. La influencia directa ejercida por los productores o consumidores indígenas, existe como lo han demostrado algunos estudios o ensayos analíticos, pero en un mínimo grado, con lo que no quedan satisfechas las exigencias de los críticos que se preguntan por una más clara y amplia realidad del posible americanismo artístico colonial, la influencia indirecta, la mayor y la más variada, se siente vagamente, es casi inaprensible, pero por esto mismo se hace más sugestiva y la cacería de sus expresiones requiere de más tacto y agudeza para que no escapen a justos análisis (figuras 7 y 8 ).

La influencia selectiva es propia de pueblos conquistados o que por alguna circunstancia política, militar o económica, padecen sojuzgamiento, pero que como pueblos, se distinguen por una vigorosa raiz cultural La influencia por selección explica en parte ese fenómeno que se reitera en la historia de "el conquistador conquistado", verbigracia Roma-Grecia o nuestro caso España-América indigena y aun en ocasiones contemporáneas, imperialismo sajón y subdesarrollo latinoamericano.

La relación del productor original de un hecho cultural y el receptor dominado, hace de la dependencia del receptor un obligado selector y en esto se basa su influencia. Dicha influencia produce una reciprocidad que acaba por re-crear o "contrahacer" el objeto cultural intermediario, lo que le hace distinto así a la pureza de intención del productor dominante, sin que tampoco se identifique como creación propia del receptor Esta presión de circunstancias condiciona de tal manera al objeto de relación que lo hace distinto y en ello, y de este meollo conflictivo, brota el carácter de lo que llamamos "arte colonial'".

El fenómeno se reitera, y así se dio en otros casos de imposición cultural como lo fueron el neoclásico y la influencia francesa durante el siglo XIX, y hasta el internacionalismo de nuestro siglo que no deja de obligar a los pueblos más débiles a producir un arte de rasgos "coloniales".

Un pueblo indígena, que curiosamente en nuestra circunstancia, sociopolítica, la palabra sugiere asociaciones con el término indigente, aunque en su acepción son distintos, en la realidad llegan a ser coincidentes, un pueblo indigente, para nuestro caso el productor del arte colonial, el indígena, selecciona de tal manera la lluvia de valores y conceptos culturales impuestos, tanto estéticos como ideológicos, que acaba, por instintiva decantación, en acumular únicamente los que le son afines, y de esta manera se manifiesta tal similitud con sus gustos o conceptos, preconcebidos o subyacentes, que éstos parecen aflorar en forma prístina como si el fenómeno fuera a la inversa, o sea formal directo, que es como más se le ha buscado encontrar. 
A este matiz diferenciante, por selección, es lo que a falta de otra explicación llamamos influencia indígena, influencia que por no quedar plenamente dilucidada hay quienes no se satisfacen ante la fácil etiqueta y se la rechaza como auténtica influencia indígena, o mestiza, o regional, y al no quedar clara la diferencia entre lo producido estilisticamente en América y lo europeo, tienen que hacerse distingos entre lo metropolitano y lo provincial, quedando el segundo con un sesgo peyorativo y como una recaida en la injusticia de aplicar términos no apropiados pues si lo de "mestizo" se rechaza por implicaciones raciales (que como lo hizo notar Pal Kelemen, no las tiene), lo de "provincial", con mayor razón debe impugnarse, pues implica razones de simple administración político-geográfico-gubernamentales.

Es más, consideramos que la obra de los dominadores españoles, constructores o simples artesanos, que para nuestro caso muestran una aparente influencia indígena, ésta se deberá de una u otra manera a que su creatividad se doblegó al gusto de quienes estaba destinada para cumplir así su función efectiva por analogia, y también creemos, como observación al margen, que no se debe pasar por alto el hecho de que, en el arte colonial, de tan esencial expresión y servicio religioso, las diferencias del clero también influyen, pues uno era el de los pueblos indígenas y otro el de las catedrales, uno el del alarife popular y otro el del maestro mayor y así el problema se complica, porque el clero español, soterrado en un pueblo indígena, también debió seleccionar lo más hispánico y afín a él, para sentirse en refugio, como ínsula de su terruño, en medio de la vastedad americana, esto explica también, en parte, que el posterior clero indigena, el de países independientes, durante el siglo XIX, no se "hallara" en templos de españoles que le eran ajenos, y los destruyó o transformó con ese trauma-lamento de que "no merecemos lo que tenemos".

Ineludiblemente nos asalta otra pregunta con frecuencia formulada al aceptar que esta influencia indigena por selección es notable sobre todo en lo decorativo, pero ¿y en lo arquitectónico en sí?, ¿y en los valores espaciales y volumétricos? Consideramos que también la hay, sólo que muy escasamente estudiada, se nota en el sentido de natural asimetría, de ese algo orgánico irregular muy americano, logrado por adiciones y renozaciones, que de generación en generación se pretenden hacer en los templos "de pueblo", que nunca están terminados, se están haciendo, están vivos, crecen y se alimentan con el tiempo, de aqui la pugna popular, sobre todo de los indígenas, contra las autoridades que ven al monumento como "testimonio del pasado", como historia estática, no con la fórmula viva que el pueblo, por su fe, le quiere sustentar. Hay un cierto animismo de callado desarrollo vital en los volúmenes de templo popular, una especie de vida adormecida que surge con esas obsesivas renovaciones y no precisamente restauraciones que se les hacen. Ese querer adicionar y cambiar todo, nos recuerda el ciclo nuevo indígena en que el templo se renovaba por completo, a diferencia del estatismo europeo.

Podría decirse que el gusto por lo irregular también lo hay en España, pero allá es más una acumulación, un enriquecimiento muy acorde con el carácter 
español de cultura aluvial, como se la ha llamado, pero aquí la idea es, si no de cambio total, sí al menos de iransfiguración, en este rehacerse constantemente algunos monumentos, para desesperación de conservadores integristas y restauradores puristas.

Sin duda habría que discutir y profundizar más todo esto, pero sí creemos que hay un subyacente gusto selectivo "ameriridio" hasta en estos casos que, como necesidad expresiva popular, son campo abierto al análisis formal

Como ilustración a estas consideraciones, y en razón de brevedad, tan sólo cabe mostrar algunos ejemplos en que se plasma el selectivo atavismo estético de América.

¿Puede considerarse casual tan sólo debido al clima y los materiales que Lima y el Cuzco sean tan diferentes?; una de madera y estuco y la otra pétrea o ¿también influyen sus distintos antecedentes plásticos prehispánicos? (figuras 9 y 10 )

Considerando tan sólo al Cuzco, pensamos que sin la intención de copiar la grandeza incaica de sus muros, sí hay una pretendida emulación disinta en muchas de sus obras coloniales, en las que los pétreos almohadillados manieristas y barrocos, se escogieron preferentemente como prueba y prolongación de la reciedumbre de la ciudad, como clara y hasta sin duda inconsciente influencia por selección de lo prehispánico sobre lo colonial (figuras 11 a 21)

Durante el aislamiento colonial de la península de Yucatán, fructificó un florilegio de espadañas eclesiásticas que con total predominio de ellas, sobre la presencia de unas cuantas sobrias torres, sólo se explica como un reminiscente gusto enraizado en el sentido plástico maya de las cresterias, las que airosas se yerguen sobre masivas formas y se taladran sobre el llano horizonte, de manera tan similar como distinta de los cristianos campanarios. Así que, jugando barrocamente con la forma de las palabras, existe, por escogimiento, una clara influencia en la secuencia, más no consecuencia de la copia o la intencional herencia (figuras 22 a 27 ).

$Y$ para terminari, el caso de una influencia selectiva que no podemos considerar directa, sino por el contrario, más bien una especie de indirecta involución representada por la Capilla del Rosario y Tonantzintla en Puebla

La Capilla del Rosario siempre se ha considerado como la orgullosa expresión de afirmación criolla que en 1690 ya adquiere conciencia (figura 28), y la logra por su exacerbación formal y teológica de las yeserías andaluzas, este criollo barroco se expresa con alma escolástica y piel de trama mudéjar y manierista, escogiendo lo que de sus directos padres peninsulares hereda y exalta.

Por su lado, Tonantzintla (figura 29), que ya no sabemos calificar si de indigena, mestiza, popular, o todo ello junto, trata de emular la obra criolla y selecciona lo que mejor le va, como lo hace ver Pedro Rojas en su estudio monográfico del monumento ${ }^{22} \mathrm{Y}$ el ilustre Francisco de la Maza, poco afecto a

* Rojas, Pedro Timamk zmla Colección de Arte Núm. 2. WNAM1, 2a edición México 1978 
la aceptación de influencias indígenas, y más bien inclinado al carácter criollo del arte colonial, ante Tonantzintla no puede menos que reconocer su ancestral espíritu nativo y nos dice bellamente cómo, en la plenitud barroca:

....surge Tonantzintla bajo el manto de la ortodoxia pero sin ser la obra teológica que es, por ejemplo, la Capilla del Rosario de Puebla No es tampoco que sea una iglesia heterodoxa, es sincrética. Es el tlalocan del siglo XVIII Es el tlalocan con vestiduras católicas y aún con religiosidad católica, pero teñida de trascendencias y realidades prehispánicas. Es, nuevamente, el paraíso terrenal de flores y frutos ${ }^{23}$

Resurgimiento y pervivencia de las viejas culturas, en el nuevo mundo, bajo el ropaje impuesto que así se hace hábito propio (figura 30).

Diremos, para terminar, que lo propuesto como influencia por selección es, a fin de cuentas, tan sólo una actitud comprensiva de las manifestaciones culturales del dominado, que no por así estarlo, sus formas de comunicación son necesariamente inferiores, esta comprensión requiere a la vez, para dar su fruto verdadero, de una dosis en que se equilibren los ingredientes de razonamiento, aceptación y amor.

23 De la Maza, Francisco. "Tonantzintla, Paraíso" En la revista Sembradores de amistad. Monterrey, NL Junio de 1965, Año XVII Vol. XX Núm 164, p. 3 